I Universidade de Brasília (UnB), Departamento de Sociologia,

Brasília, DF, Brasil

edu@dimitrov.com.br

Eduardo Dimitrov'

\title{
LULA CARDOSO AYRES: MODERNISTA EM PERNAMBUCO, FOLCLÓRICO EM SÃO PAULO*
}

Este artigo pretende explorar a trajetória de Lula Cardoso Ayres para examinar quais eram as possibilidades que um pintor fixado em uma cidade periférica aos emergentes centros legitimadores da produção cultural (Rio de Janeiro e São Paulo) vislumbrava para sua carreira. Lula é, ainda hoje, considerado um dos maiores pintores do modernismo pernambucano. Modernismo esse compreendido tal como Freyre o formulava: um modernismo regionalista. Analisando, porém, sua trajetória, é possível identificar momentos de tensão, no qual Lula pretendia ser reconhecido nacionalmente não como um pintor "dos motivos da região", mas como um pintor, sem adjetivos folclorizantes. O que se verificou na pesquisa de sua trajetória foi, justamente, a confluência de muitos fatores que direcionaram Lula para uma produção pictórica identificada como regional mesmo que, em alguns momentos, essa não fosse sua intenção expressa.

Para isso, este artigo seguirá o seguinte percurso. Em um primeiro momento se apresentarão alguns elementos formativos na trajetória de Lula Cardoso Ayres e sua circulação entre Recife, Rio de Janeiro e Paris. Um segundo movimento será o de mostrar como alguns intelectuais reagiram às obras de Lula e tentaram postular leituras específicas para elas. Sobretudo as interpretações de Gilberto Freyre foram, ao mesmo tempo, importantes no sentido de abrir portas para sua carreira, mas, também, traziam entraves, os quais Lula procurou superar. Num terceiro momento, irá ser explorado o ponto de vista de 
Lula que se evidencia em algumas trocas de cartas com Pietro Maria Bardi e sua tentativa de se desvencilhar das leituras folclorizantes. Por fim, retomam-se em linhas gerais a trajetória do artista e o contexto social, político e intelectual do Recife de modo a lançar nova luz sobre determinações sociais para as suas escolhas artísticas.

Não se trata aqui de avaliar se a produção estética de Ayres poderia ser classificada com certo ideal de modernismo. Um olhar acurado, informado pela história da arte, poderia questionar essa classificação tanto pelas soluções estéticas presentes nas obras do artista quanto por sua trajetória formativa (aulas com Denis, Amoedo e Chambelland não são propriamente o percurso mais ortodoxo de um modernista nos anos I920 e I930). O que aqui importa são as categorias utilizadas pelos agentes. Nesse sentido, tanto a fortuna crítica da época quanto a mais recente consideram Ayres um pintor "modernista". O significado desse "modernismo" só pode ser compreendido nos diferentes contextos em que aparece. Por vezes se opõe a folclórico ou mesmo regional; por vezes surge como sinônimo de "atual", coadunado com os movimentos recentes da arte praticada em São Paulo ou Paris. Fato é que ser reconhecido como modernista é algo positivado pela fortuna crítica e almejado pelo próprio pintor. Desse modo, ao longo do texto, serão grafadas entre aspas as formas de classificação utilizadas pelos agentes.

\section{EXPOENTE REGIONALISTA}

Lula Cardoso Ayres - ao lado de Cícero Dias e Manoel Bandeira (o pintor) - foi um dos artistas mais próximos de Gilberto Freyre. Essa proximidade se deu tanto pela origem social semelhante - ambos de famílias ligadas à produção do açúcar - quanto pela amizade e compadrio estabelecidos entre eles. Ayres ilustrou diversas obras de Freyre, enquanto o ensaísta escreveu elogiosos artigos, apresentações e cartas de recomendação frisando as qualidades do pintor. Essa cooperação, extremamente proveitosa para ambos os lados, tornou Lula um expoente da pintura regionalista. Suas obras mais conhecidas, ainda que pouco difundidas para além de Pernambuco, são aquelas que fazem menção ao que comumente passou-se a identificar como típico da região Nordeste: bumba meu boi, frevo, maracatu, carnaval, trabalhadores rurais, bonecos de barro etc.

Tendo iniciado seus estudos com o alemão radicado no Recife Heinrich Moser, Lula Cardoso Ayres (I9I0-I987) frequentou o ateliê de Maurice Denis

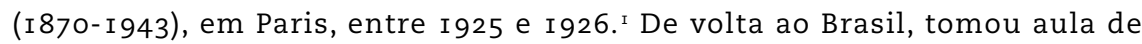
modelo vivo com Rodolfo Amoedo, ${ }^{2}$ na Escola Nacional de Belas Artes, e estudou desenho e pintura no ateliê de Carlos Chambelland. ${ }^{3}$

As dificuldades financeiras obrigaram-no a interromper seus estudos no Rio de Janeiro, em I932, para auxiliar o pai na administração da usina de açúcar da família em Cucaú, onde residiu até i944. O que poderia ser visto como amea- 
ça à formação do pintor foi interpretado, anos depois, como sendo sua salvação. No catálogo da exposição ocorrida no Museu de Arte de São Paulo (Masp), em I960, Freyre (I960: 9) afirma: "Sua fase de residência no interior de Pernambuco foi para ele decisiva no sentido de aproximá-lo de fontes telúricas, populares e folclóricas de inspiração, até torná-lo um íntimo dessas fontes, por outros conhecidas apenas turisticamente".4

Gilberto Freyre vê, na combinação entre a formação avançada em artes, tanto no Rio de Janeiro como em Paris, e a experiência de ter vivido no interior de Pernambuco, próximo às "tradições populares", algo que o diferenciava dos demais artistas modernistas que conheciam apenas os "ismos" europeus e a cultura do povo por "viagens turísticas". 5

Durante sua residência no engenho, Lula produziu inúmeras fotografias retratando os trabalhadores rurais. Tal como na figura I, é comum sua opção pelo enquadramento de baixo para cima, colocando o trabalhador em uma posição de dignidade, mesmo que portando indícios claros de pobreza: os pés descalços, o rosto marcado pelo sol e pelo trabalho pesado.

A roupa simples em panos de chita, abundantes nas fotos, será transposta para os quadros posteriores, quando esses trabalhadores pobres se transformarão em bonecos de barro.

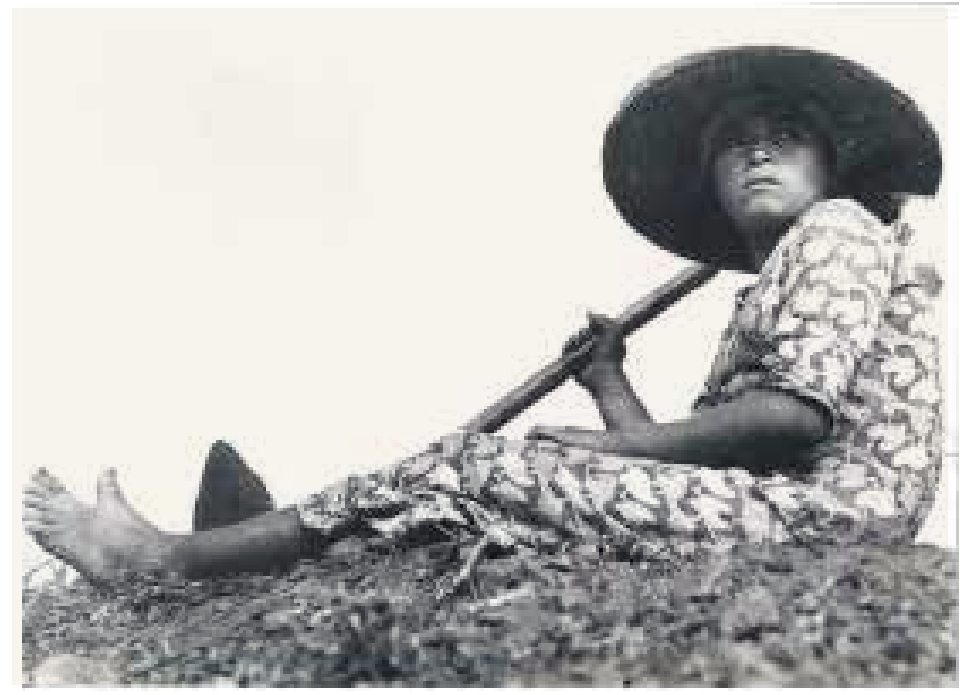

I

Engenho Cucaú

Fotografia, I940 (d.a.)

Col. Fundação Joaquim Nabuco

Reproduzida em Coletiva (Fundação..., 20I I) 
A capacidade de amalgamar fontes populares com formas "modernas" foi percebida por vários críticos, entre eles Alberto da Costa e Silva (2009: 72):

O que é permanente, nesta obra que se modifica, moderniza e aprofunda no decorrer de cinquenta anos, é a fidelidade de Lula à aliança entre o conhecimento mágico e a captação da beleza de sua província natal, de um Pernambuco que em seus quadros assume uma verdade própria.

O esforço de Lula em fazer referências ao que vinha sendo construído como arte popular é de fato inegável. ${ }^{6}$ Basta ver a série baseada em bonecos de barro, na qual associa suas fotografias às esculturas "populares" criadas por artesãos das cidades de Caruaru, Garanhuns e Canhotinho, como se pode ver nas telas Passeio a Cavalo (I944, figura 2) e Trabalhadores no Eito (I943, figura 3).

No quadro Trabalhadores no Eito, percebe-se, no primeiro plano à esquerda, uma mulher de costas, tendo nos braços uma criança de perfil olhando para seu rosto. Em um segundo plano, sete personagens com enxadas nas mãos revolvendo a terra em uma fileira enviesada, do canto direito inferior ao es querdo superior. A posição sequenciada das figuras respeita os traços também diagonais da terra, colaborando para acentuar a perspectiva. No fundo, vê-se o campo ainda sem nenhum plantio, duas árvores aparentadas a coqueiros ou palmeiras e três colinas, como que simbolizando a natureza rala, local.

Todos os lavradores têm o mesmo formato de corpo: volumoso e arredondado. Não possuem características próprias; não constituem individualidades. Assemelham-se a bonecos pintados, não pessoas. Os homens estão de chapéus, as mulheres usam lenços ou apenas têm os cabelos presos. Diferença mais sutil são as saias e as calças, quase imperceptíveis em função do movimento das figuras. É só por essas diferenças que se distinguem homens e mulheres. ${ }^{7}$

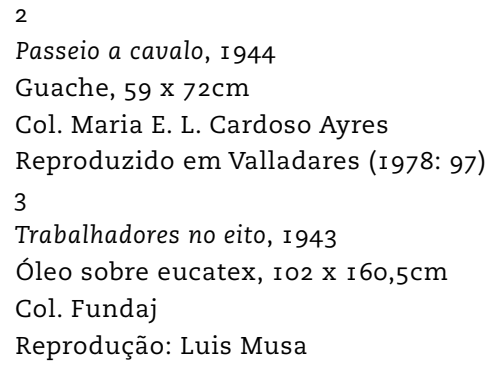


2
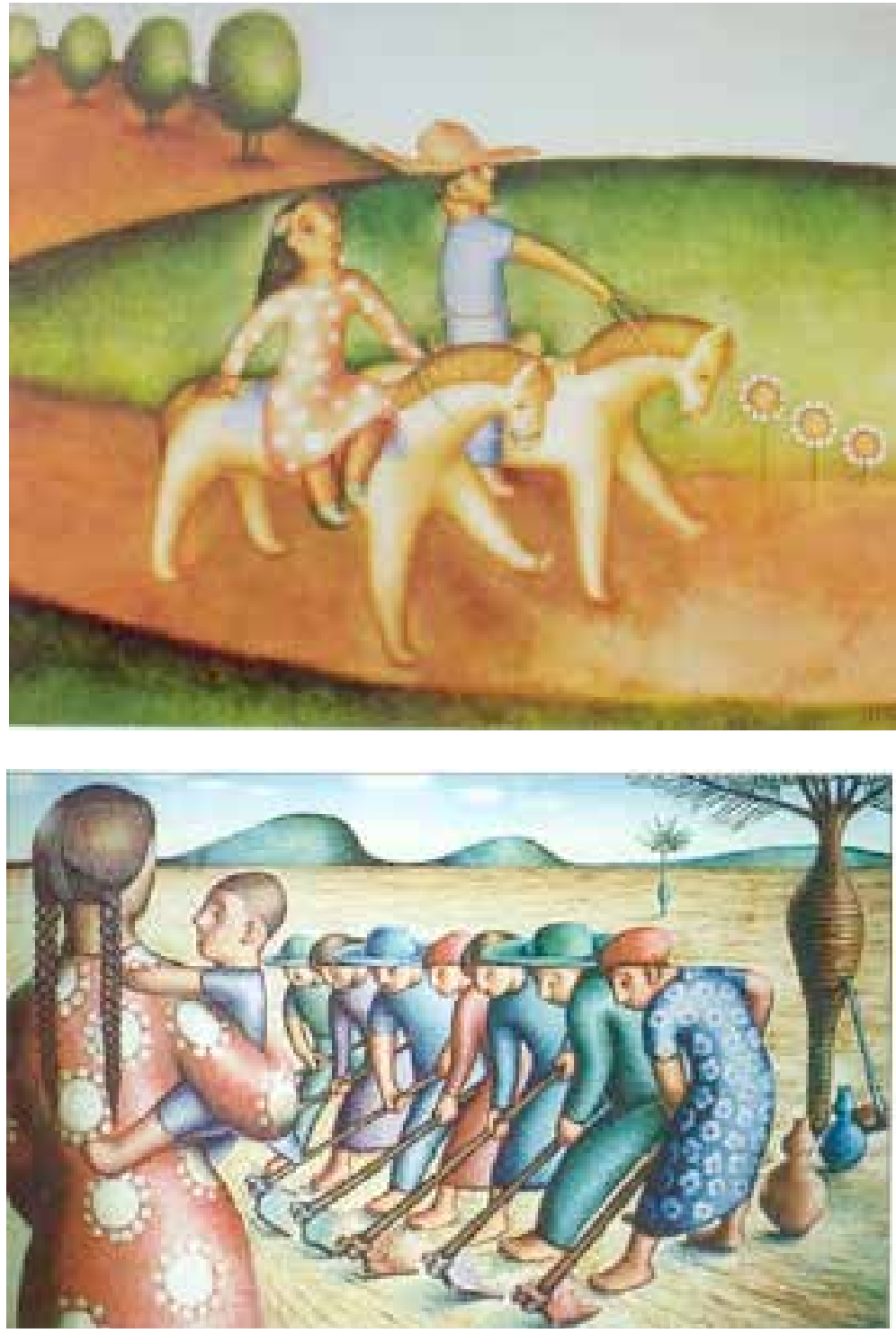
Seus corpos mantêm profundo sincronismo de movimento: todos com o mesmo ritmo nos golpes de enxada. As cores azul, verde, vermelho e roxo se alternam nas roupas, intensificando ainda mais a ideia de trabalho conjunto e harmonizado dos personagens. Até mesmo os ferros das enxadas são coloridos. Em um ambiente tão inóspito, desértico, trabalhadores no eito - uma das piores condições de servidão - figuram como personagens limpos, coloridos, elevados.

São desse mesmo período algumas telas consideradas por Freyre mais "surrealistas", que lembrariam um ambiente onírico, povoadas por vultos fantasmagóricos como é o caso de Vestindo a noiva (figura 4), Sofá mal-assombrado (figura 5) ou Cabriolé mal-assombrado (figura 6).

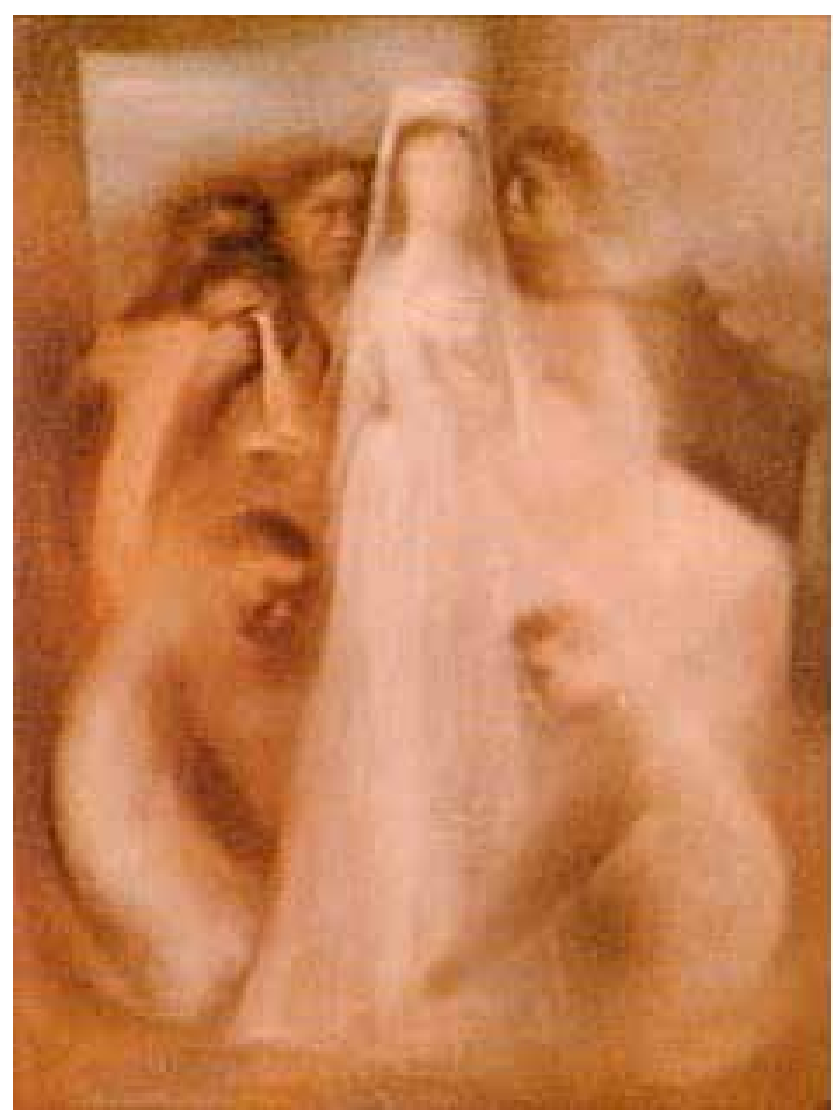


5
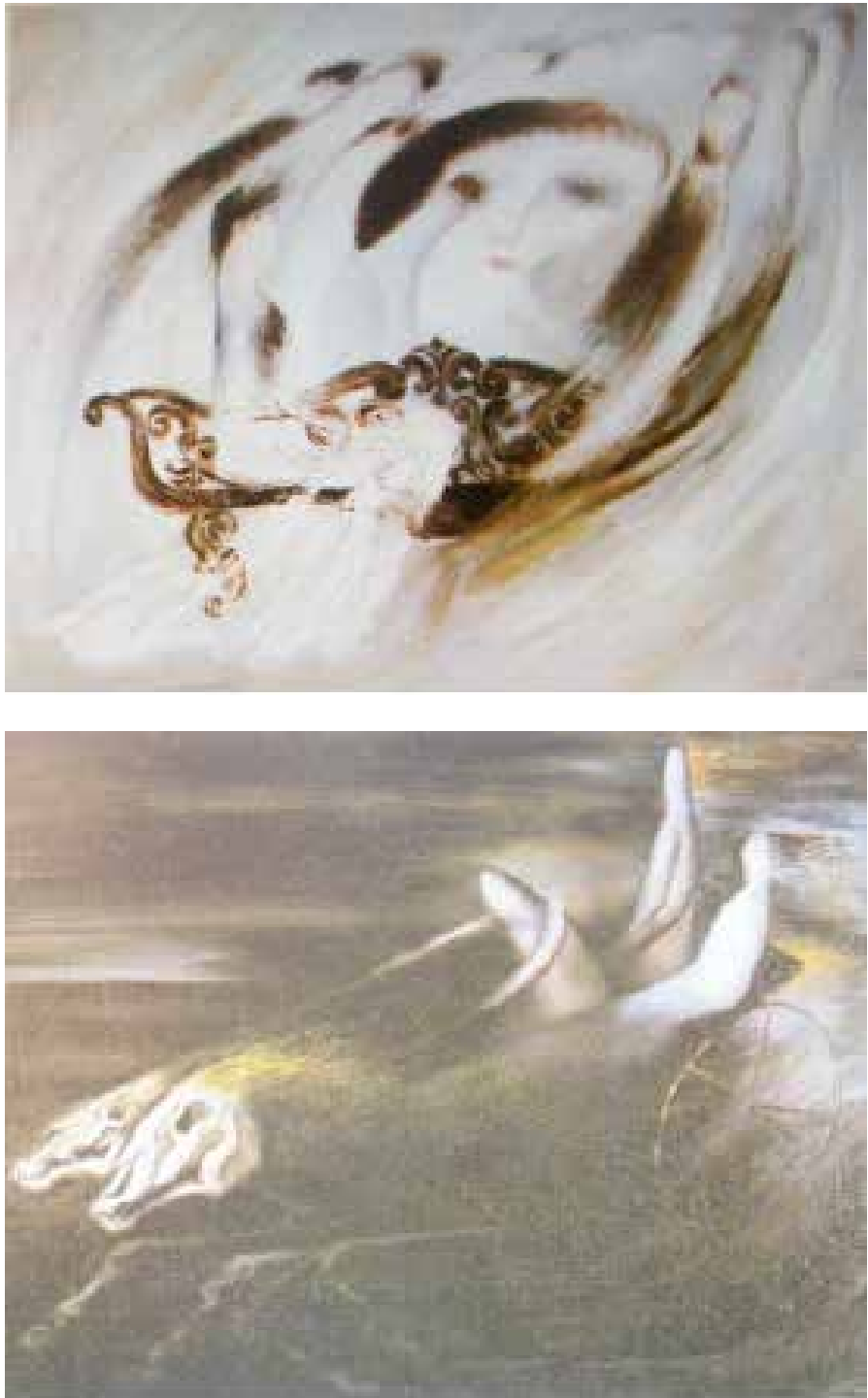

5

Sofá mal-assombrado, I945

Óleo sobre tela, 73 x $92 \mathrm{~cm}$

Col. Luís Cardoso Ayres Filho

Reproduzido em Valladares (I978: I Io)

6

Cabriolé mal-assombrado, I 945

Óleo sobre tela, 73 x $92 \mathrm{~cm}$

Col. João Cardoso Ayres Neto

Reproduzido em Valladares (I978: I07) 


\title{
LULA CARDOSO AYRES SEGUNDO GILBERTO FREYRE
}

Mesmo essa investida, chamada por Freyre de "surrealista", traz uma ligação com o referente. É possível, na maioria das vezes, reconhecer portões, sofás, janelas, figuras humanas e fantasmas. Gilberto Freyre ainda associa essas telas "surrealistas" a elementos da região na qual Lula estava imerso. Diz o sociólogo, no mesmo catálogo da exposição do Masp, citando depoimentos do próprio Lula:

\begin{abstract}
Mais tarde, em 1943, faria Lula uma série de quadros do bumba meu boi com pretensões surrealistas [...]. E ele próprio salienta, nessa nota autobiográfica, que viria a pintar tudo isto, depois de passar por "várias etapas desde o desenho realista à inteira libertação do realismo visual, utilizando as formas reais como ponto de partida para a estilização das formas aparentemente abstratas das minhas composições mais recentes". O mesmo aconteceria com as figuras do carnaval recifense; com os maracatus, os caboclinhos, as damas dos blocos. Enfim, a sua pintura aparentemente abstrata seria o resultado de uma longa série de observações sistemáticas da realidade regional. Seus próprios mal-assombrados teriam, como forma, base regional (Freyre, I960: II; grifos do autor).
\end{abstract}

Um pouco mais adiante em seu texto, Freyre recupera uma citação de Picasso para comprovar a "modernidade" das telas de Ayres e, ao mesmo tempo, seu vínculo com a tradição e a região.

O que nos faz pensar em palavras de Picasso: "Não há arte abstrata. Deve-se sempre partir de alguma coisa. Depois, pode-se remover tudo que seja traço de realidade. Já então não há perigo algum (para a realidade) porque a ideia do objeto terá deixado uma marca indelével" (Freyre, I960: I2).

Nessas duas passagens, Freyre está preocupado em guiar o olhar dos visitantes da exposição de I96o para o fato de Lula ser capaz de fazer arte "abstrata" sem perder os elementos "da realidade regional" que a vivência em sua fazenda lhe fornecera. Nos termos de Freyre, Lula seria um artista "moderno" sem ser "modernista": suas telas seriam capazes de conciliar as inovações formais e as tradições regionais, uma vez que, por ter vivido em sua região, ele não fora um mero turista, e as tradições realmente teriam sido introjetadas em sua personalidade. Cabe ressaltar, que algumas telas apresentadas eram datadas das décadas de I930, I940 e I950, logo, Freyre buscava, também, atualizar as soluções artísticas de Lula feitas em outro contexto para o novo debate em torno do abstracionismo que se instaurou no Brasil a partir das Bienais de São Paulo.

O crítico Clarival do Prado Valladares, em texto posterior aos de Freyre, recusa a aproximação dessas telas ao surrealismo, justamente por nelas ser fundamental o enraizamento "à vertente telúrica de seu universo". Diz o crítico:

Não há surrealismo em nenhuma de suas assombrações de I944-I946, ou dos sobrados de I964-I966, e nem mesmo na série de transfigurações do Bumba meu boi de I945. Não há porque todos esses trabalhos se situam no plano narrativo, e não no plano onírico. Do mesmo modo que não é bastante ser ilusão de ótica para se reconhecer, sob critério crítico, uma proposta cinética (optical art), do 
mesmo modo que não basta negar a figura para se naturalizar abstração, pode-se dizer que para se validar uma concepção surrealista exige-se mais que anamorfose (Valladares, I978: 105).

Essa apreciação expressa no texto de Valladares permite matizar a interpretação de Freyre, que liga diretamente Lula ao surrealismo. Aproximá-lo dessa vanguarda poderia ser uma chave para maior aceitação das obras pelo público de São Paulo que, aos olhos de Freyre, era a capital "modernista", ou seja, adepta às mais recentes inovações estéticas importadas da Europa. Assim como Valladares, o ensaísta valoriza a vertente telúrica do universo de Lula afirmando que se realiza "agora a exposição de um pintor pernambucano, personalíssimo na sua arte criadora; e por isto mesmo desprezado pelos estetas sectariamente abstracionistas tanto de São Paulo como do Rio" (Freyre, I 960: I7).

Freyre tentava contemporizar, de acordo com a sua própria definição de arte moderna, o vínculo regional que o artista possuía com as mais avançadas descobertas no campo das artes plásticas. Apresentava ao público paulista, portanto, um artista "moderníssimo", capaz de combinar o "surrealismo" com as tradições da cerâmica figurativa; a vanguarda com o primitivo.

De qualquer maneira, o conjunto das telas que Lula Cardoso Ayres levou para São Paulo destoa daquelas mais figurativas executadas nos anos I940. Nos 20 quadros, ${ }^{8}$ Lula explora esquematismos - por vezes mais, por vezes menos - relacionados a formas e figuras pintadas anteriormente. É o caso, por exemplo, da semelhança entre as formas presentes em Coruja do bumba meu boi (figura 7) e o quadro de Título desconhecido I (figura 8). ${ }^{9}$

A Coruja do bumba meu boi traz um homem fantasiado e preso a um enquadramento que lembra um retrato. O fundo neutro não o ancora em uma situação específica. Sua vinculação com o bumba meu boi se dá, aos olhos de um leigo, apenas pelo título. O quadro, como se fosse um desenho técnico de biólogo a descrever um animal, elenca as características daquele personagem: túnica preta, máscara de coruja, bengala na mão. O corpo levemente torcido em espiral. As costas e o seu ombro direito estão dispostos em três quartos; seus olhos miram o espectador; o quadril e as pernas estão praticamente de perfil. A ponta do pé esquerdo, seguindo o movimento da cabeça, sugere uma futura rotação de todo o corpo num eixo paralelo ao da bengala apoiada.

O volume da máscara e do que parece ser uma corcunda, acentuada pela posição do ombro, são elementos fundamentais para que se estabeleça uma relação com o quadro de Título desconhecido I, no qual há formas mais esquemáticas. Com o mesmo enquadramento e fundo também neutro, uma figura geométrica lembra um polígono torcido sob um eixo vertical; uma coluna vertebral representada pela linha branca longitudinal.

Na parte superior, o lado direito levemente mais baixo que o esquerdo remete à mesma relação entre as posições da cabeça e da corcunda. A silhueta do homem, com o abdômen aparentemente afinado pelo movimento de giro, 
repete-se nos polígonos. Mesmo o pé esquerdo, com apenas a ponta apoiada, indicando o movimento, possui um rebatimento no desequilíbrio causado pela relação entre a base horizontal da metade esquerda do polígono e a aparente suspensão do plano à direita. O braço e a bengala surgem como as referências mais diretas entre as duas imagens.

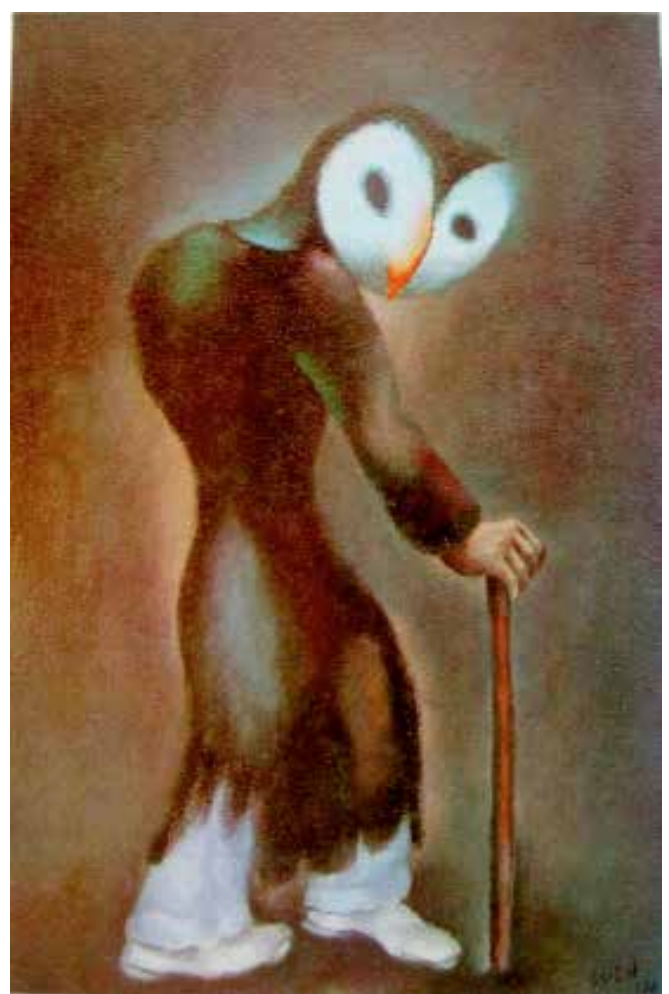

7

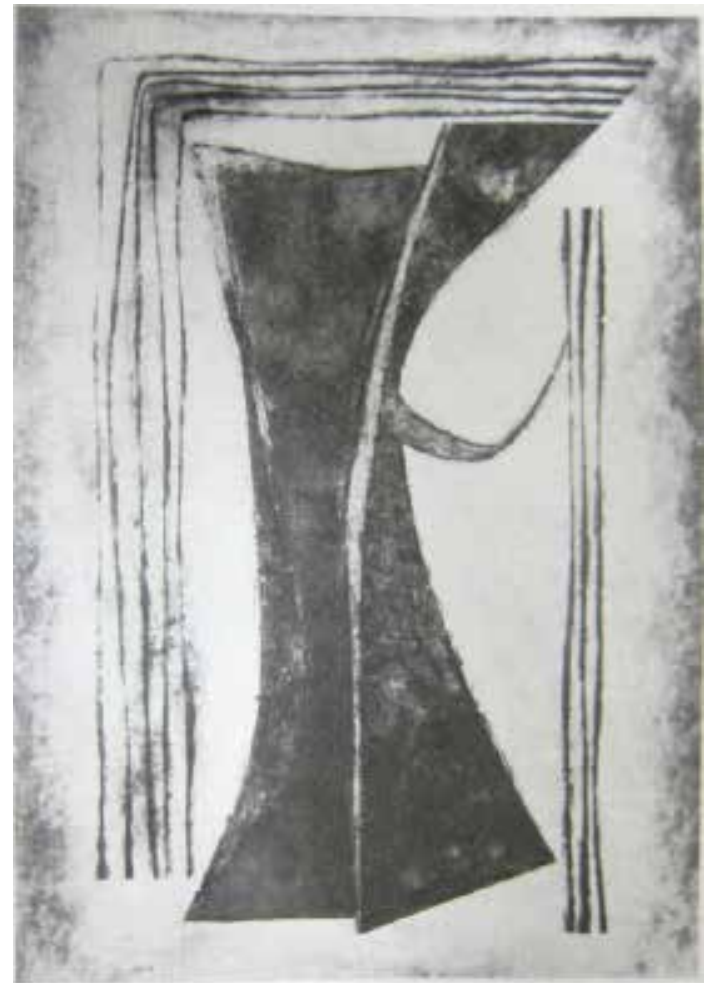

8

7

Coruja do bumba meu boi, I94I

Guache, $42 \times 28 \mathrm{~cm}$

Col. do artista

Reprodução Valladares (I978: 58)

8

Título desconhecido I, I96o (d.a.).

Reprodução em Ayres (I960) 
Algumas telas da exposição de I960 no Masp trazem referências mais evidentes ao universo pictórico de Lula. Em muitas delas é possível vislumbrar bois, pássaros, telhados. ${ }^{10}$ Em outras, essas referências podem ser sutis, como no caso do Título desconhecido I e da Coruja do bumba meu boi, como foi visto. Ou ainda em Composição [bumba meu boi] (figura Io) também exibida na exposição de I 960 e adquirida pelo Masp que faz referência à tela Cavalo marinho do bumba meu boi (figura 9).

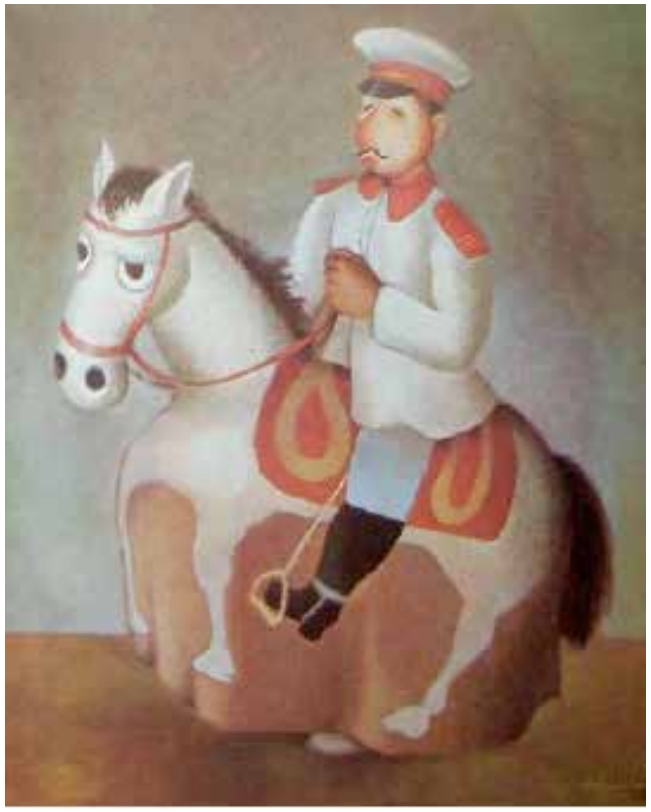

9

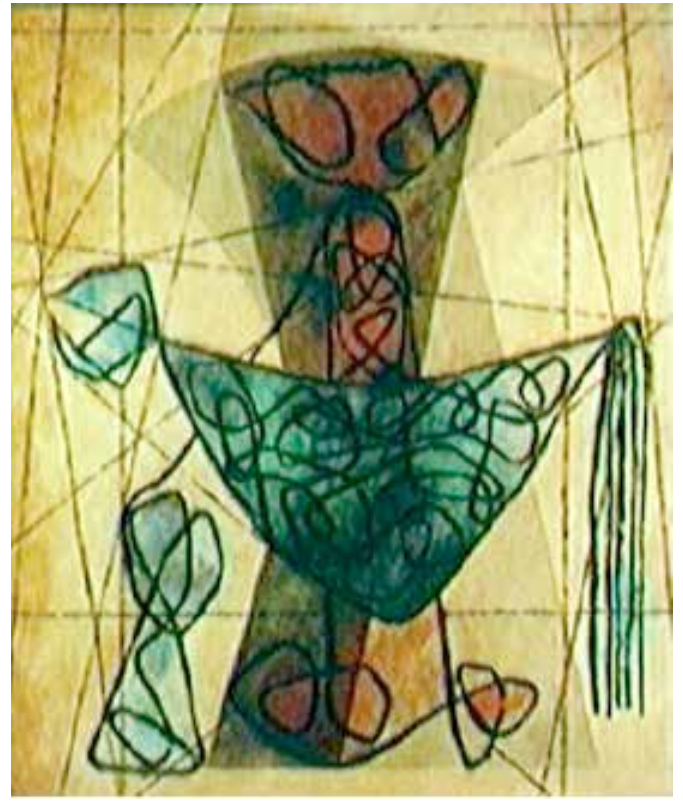

IO

9

Cavalo marinho do bumba meu boi, I94I

Guache, $47 \times 43 \mathrm{~cm}$

Col. Instituto Lula Cardoso Ayres

Reproduzido em Valladares (I978: 53)

IO

Composição [bumba meu boi], I96o (d.a.)

Óleo sobre tela, 95 x 95cm

Col. Masp

Reproduzido na Enciclopédia Virtual

do Instituto Itaú Cultural (2013) 
Título desconhecido 2 (figura I I), aparentemente, beira a abstração; no entanto, tomando a produção de Lula como um todo, percebe-se que esse remete a outros quadros, dialogando com eles, como o caso de Jaraguá do bumba meu boi, de I94I (figura I2). O crânio de cavalo ou boi, a incidência da luz sobre o peito do homem fantasiado, a formação triangular da composição são alguns dos elementos que permitem associar uma tela a outra. Há telas, porém, que exploram mais a fundo o rompimento com um referente, como é o caso de Título desconhecido 3 (figura I3), mas que ainda assim mantém sua referência aos caboclos de lança do maracatu rural.

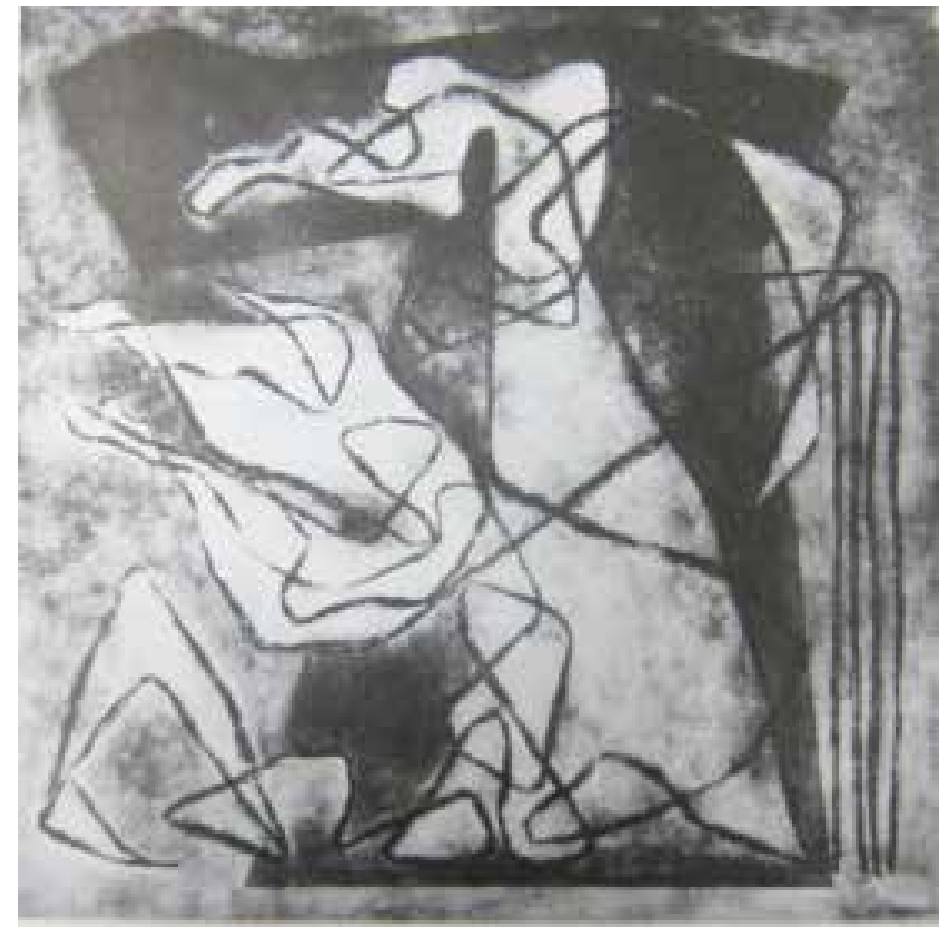




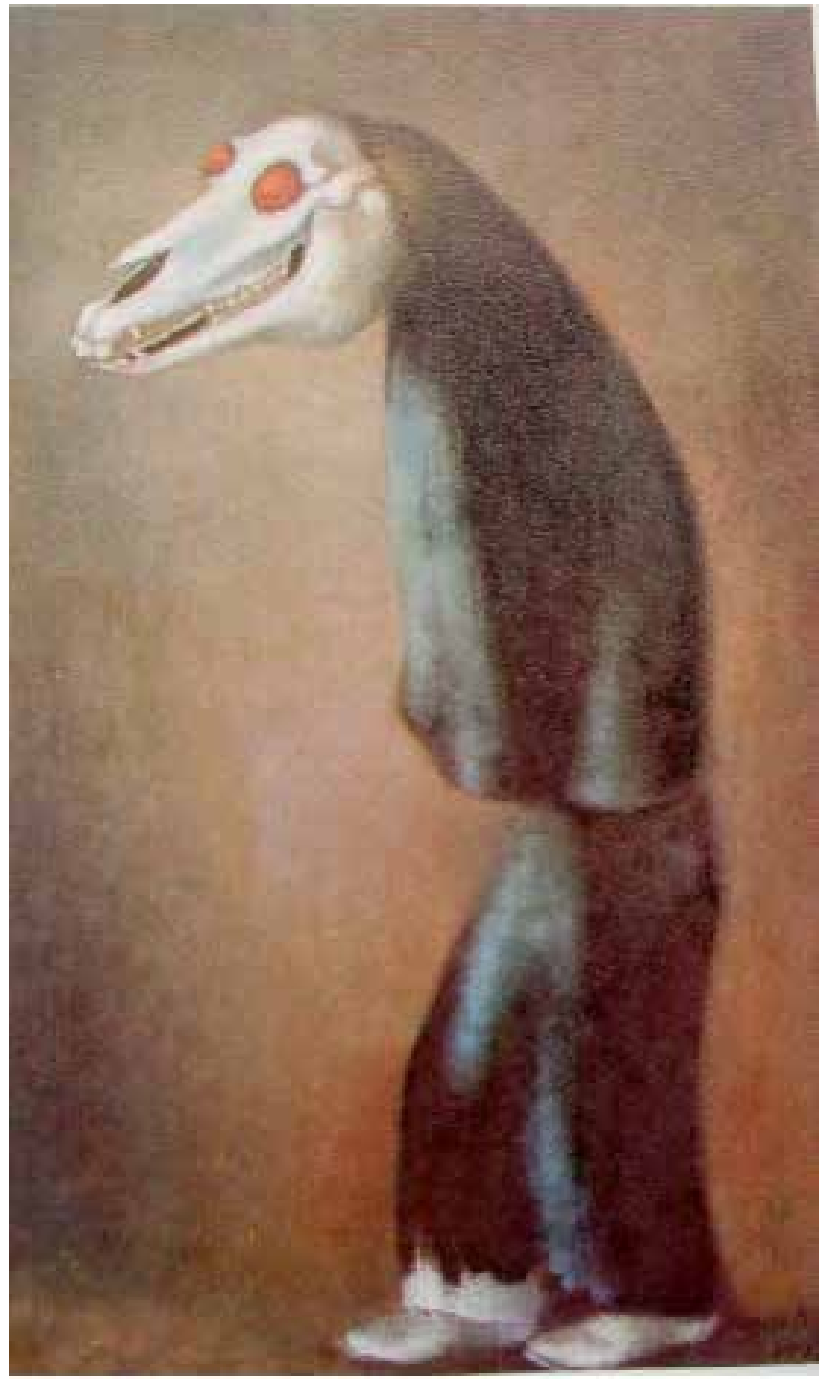

I 2

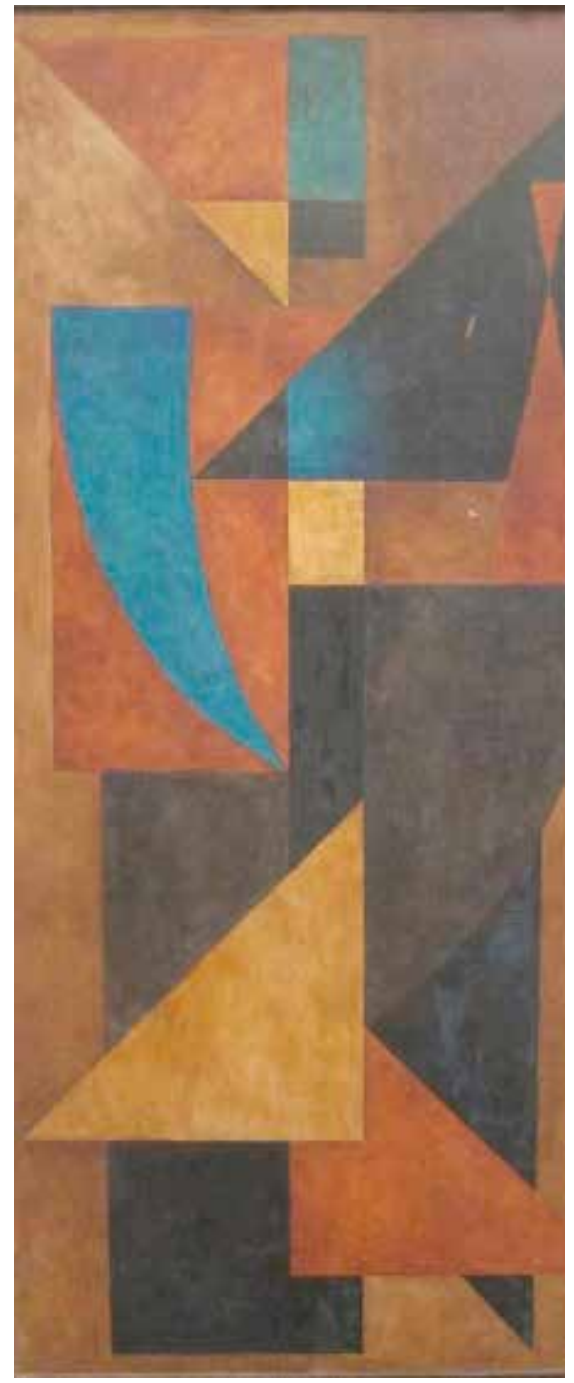

I 3

I 2

Jaraguá do bumba meu boi, I94I

Guache, 50 x $31 \mathrm{~cm}$

Col. do artista

Reproduzido em Valladares(I978: 59)

I 3

Título desconhecido 3 [Caboclo de lança], I96o

Óleo sobre Eucatex (?)

Col. Instituto Lula Cardoso Ayres

Reprodução: Eduardo Dimitrov 
Ao mesmo tempo em que Freyre denunciava, sem especificar nomes, o descaso dos "estetas sectariamente abstracionistas" de São Paulo e do Rio de Janeiro com a obra de Ayres, ele tece elogios a Pietro M. Bardi.

Trata-se de iniciativa do Professor P. M. Bardi, sob a impressão do extraordinário valor estético da obra do artista pernambucano: tanto que está empenhado em promover outras exposições dos seus trabalhos. Nos Estados Unidos, a exposição de Lula Cardoso Ayres deverá realizar-se logo após a de São Paulo (Freyre, I960: I5-I6).

Dando a entender que a iniciativa da exposição era fruto, exclusivamente, do reconhecimento que Bardi conferiu aos trabalhos de Lula, o antropólogo alavanca a imagem do pintor como um artista "moderno" que logo teria projeção internacional. Nenhuma referência a exposições de Lula Cardoso Ayres nos Estados Unidos nesse período foi encontrada. Criou-se a expectativa sobre uma exposição em Nova York, provavelmente quando o aquarelista originário do Kansas, Frederic James (I9I5-I985), que era militar na base americana em Recife durante a Segunda Guerra Mundial, fotografou em cores algumas telas de Lula em I946. Segundo artigo de Mauro Mota (I946), ${ }^{\text {II }}$ as fotos foram feitas com a promessa de ser mostradas aos dirigentes do prestigiado Museu de Arte Moderna de Nova York. Por outro lado, James teve sua carreira ligada ao movimento regionalista americano, sendo aluno de Thomas Hart Benton (I889-I975), o que permite que se levante a hipótese de ele se ter interessado justamente pelo caráter regionalista da produção de Lula Cardoso Ayres e menos por sua "modernidade". Em outras palavras, o interesse de um pintor regionalista americano pela obra de Ayres passa a ser divulgado como o passaporte para uma carreira de reconhecimento internacional, logo associado ao que haveria de mais "moderno" nas artes. ${ }^{12}$

De todo modo, a própria argumentação de Freyre, na tentativa de valorizar seu compadre, não se deu na chave da autonomização da linguagem pictórica, e, sim, enfatizando suas ligações temáticas com a região. Ou seja, mesmo que Ayres buscasse pensar, em suas telas, em questões formais, a temática regional era mobilizada, discursivamente, com mais vigor.

\section{DIÁlOGo ENTRE LULA CARDOSO AYRES E PIETRO MARIA BARDI}

Pela observação das correspondências trocadas entre Bardi e Lula Cardoso Ayres se evidencia o quanto o pintor investiu nessa exposição, assim como em sua relação com o casal ítalo-brasileiro. ${ }^{13}$ No dia I 3 de janeiro de I960, morre a mãe de Ayres. É com essa informação que inicia sua carta escrita no dia I5 ao diretor do Masp para, logo em seguida, dizer que "com este triste fato já consumado retomo o ritmo da vida tão cheia de sofrimentos e desilusões, e volto a tratar da minha exposição que é no momento o estímulo que tenho para atenuar o grande sofrimento por que passei". 
Mais adiante, na mesma carta, ele discorre sobre suas expectativas quanto à exposição:

Estou organizando o catálogo como combinamos e resolvi deixar a lista com o número e os títulos dos quadros recentes, cerca de 70, para escolhermos os mais significativos para a exposição no Museu de Arte e outros ficarão na reserva para possíveis vendas e outras exposições em outros lugares.

Ainda não recebi notícias do Museu de Arte Moderna do Rio, certamente D. Niomar $^{14}$ não se interessou mas estou certo que depois da exposição em São Paulo vai haver interesse.

Vou retomar agora a organização da parte documental com fotografias e velhos estudos dos assuntos pintados hoje.

[...] Soube que você esteve na Bahia para a inauguração do $\mathrm{Museu}^{15}$ e gostaria também de fazer uma exposição lá, talvez em julho época das férias da Escola. ${ }^{16}$

Lula acreditava que a exposição no Masp abrir-lhe-ia muitas portas: já planejava levar mais quadros do que aqueles a expor, na expectativa de venda ou de exposições futuras, no Rio de Janeiro, na Bahia, ou - seguindo as indicações de Freyre - nos Estados Unidos. Essas expectativas justificavam o grande investimento que o artista fazia, elaborando um catálogo fartamente ilustrado, com ótima impressão e cerca de 40 páginas. Seus contatos e sua experiência na indústria gráfica certamente colaboraram para a execução desse material. ${ }^{17}$ Além de montar (selecionar as imagens, executar a diagramação etc.), Lula financiou a impressão do catálogo e a de I.00o convites em papel-cartão - Bardi apenas lhe transmitiu os dizeres que deveriam conter. Pelo que se subentende das cartas, arcou também com o transporte dos quadros e as despesas da viagem. Diz ele: "Estou numa virada louca de trabalho, pois, como você pode prever, estou gastando um dinheirão enorme nos preparos da exposição e para aguentar o repuxo, estou fazendo ainda um painel, felizmente muito bem pago, para a filial daqui da OLIVETTI". ${ }^{\text {I8 }}$

Nas curtas respostas de Bardi, ainda mais quando comparadas às do pintor, há sempre uma ponderação, uma tentativa do curador em diminuir as expectativas do artista ansioso, como, por exemplo, na carta de 22 de janeiro de I960, na qual diz: "Aconselho a não trazer muitos quadros, faça a sua escolha. Não se iluda quanto à vendagem, pois São Paulo é uma cidade onde não se adquirem obras de arte"; ${ }^{19}$ ou, ainda, a de I4 de março de I960: "Sempre lhe disse de não esperar muito de São Paulo, mas tentaremos fazer de todo o possível para um bom êxito da exposição". ${ }^{20}$

Uma das expectativas mais reveladoras para a guinada "esquemática" que Ayres imprimiu a seus quadros foi a de desvencilhar-se da imagem de um pintor voltado para documentar o folclore. 
Gilberto tem grande admiração e respeito a você [Pietro. M. Bardi] e por ser meu amigo, como é, está orgulhoso de você ter se interessado por minha pintura, pois como você sabe os entendidos da chamada "pintura pura" vinham olhando para minhas tentativas como simples registro documental do "folclore" e dos motivos da região. ${ }^{21}$

É possível pensar Ayres vivendo um dilema: ser reconhecido por Gilberto Freyre e seus colegas pernambucanos ${ }^{22}$ como um pintor moderno, por estar ligado a tradições locais ou, justamente por estar ligado a tradições locais, ser um mero folclorista aos olhos dos "entendidos da chamada 'pintura pura'". Como já se viu, na exposição do Masp, comparando os quadros que compõem o catálogo com aqueles de produção anterior, pode-se notar forte preocupação em se distanciar, cada vez mais, da referência direta e descritiva das figuras tradicionais, sem, ao mesmo tempo, as abandonar completamente.

Essa era uma posição perigosa, capaz de desagradar ambos os lados. Em artigo publicado em I96I - praticamente um ano após a exposição do Masp -, José Cláudio da Silva, lembrando-se do tempo de "arte engajada" que predominou entre os integrantes do Atelier Coletivo, ${ }^{23}$ afirma:

[as referências de] pintores brasileiros eram: Portinari, Di Cavalcanti, algum Guignard, e por uma questão de carinho para com o popular, Djanira, Heitor dos Prazeres e Cícero Dias da época do primitivismo, lamentando que ele se tivesse deturpado e caído no abstracionismo, abstracionismo igual à sarjeta. Lula era um finório, procurando sempre um ponto estratégico que desse saída para muitos lados, para poder virar casaca sem ser notado, água morna (isso eu ainda hoje penso) (Silva, I96r: Segundo Caderno).

Na mesma página de jornal em que foi publicado esse artigo de José Cláudio, anunciava-se o novo convite que Lina Bo Bardi teria feito a Lula Cardoso Ayres para expor, em julho de I96I, no Museu da Bahia, local em que atuava como diretora. Na foto (figura I4), vê-se Lula ao lado de um trabalho de sua autoria, de grandes dimensões, representando, de maneira estilizada, um caboclo de maracatu. Das expectativas explicitadas nas cartas a Pietro M. Bardi, a exposição na Bahia concretizava-se um ano depois, anunciada como um convite e reconhecimento de Lina Bo Bardi à obra "moderna" do pernambucano. Nessa página de jornal, as tensões entre os significados de ser "moderno" estavam materializadas nas diferentes posições que Lula Cardoso Ayres cristalizava, isto é, pela forma como a "tradição popular" era utilizada na fatura das obras, frente à crítica de José Claudio e frente ao reconhecimento dos Bardi.

$\mathrm{Na}$ crítica feita a partir do Sudeste, é possível vislumbrar uma tensão semelhante. Em artigo de 1965, Ferreira Gullar (1965, p. 225) escrevia sobre a exposição Opinião 65: "tenho me debatido contra a ideia de que um artista do Recife deva fazer a mesma arte que um artista de Nova Iorque ou Paris". Nesse caso, quais seriam as reais possibilidades de Ayres fazer uma arte não passível de ser vinculada ao folclore, à cultura popular, ao regionalismo? 


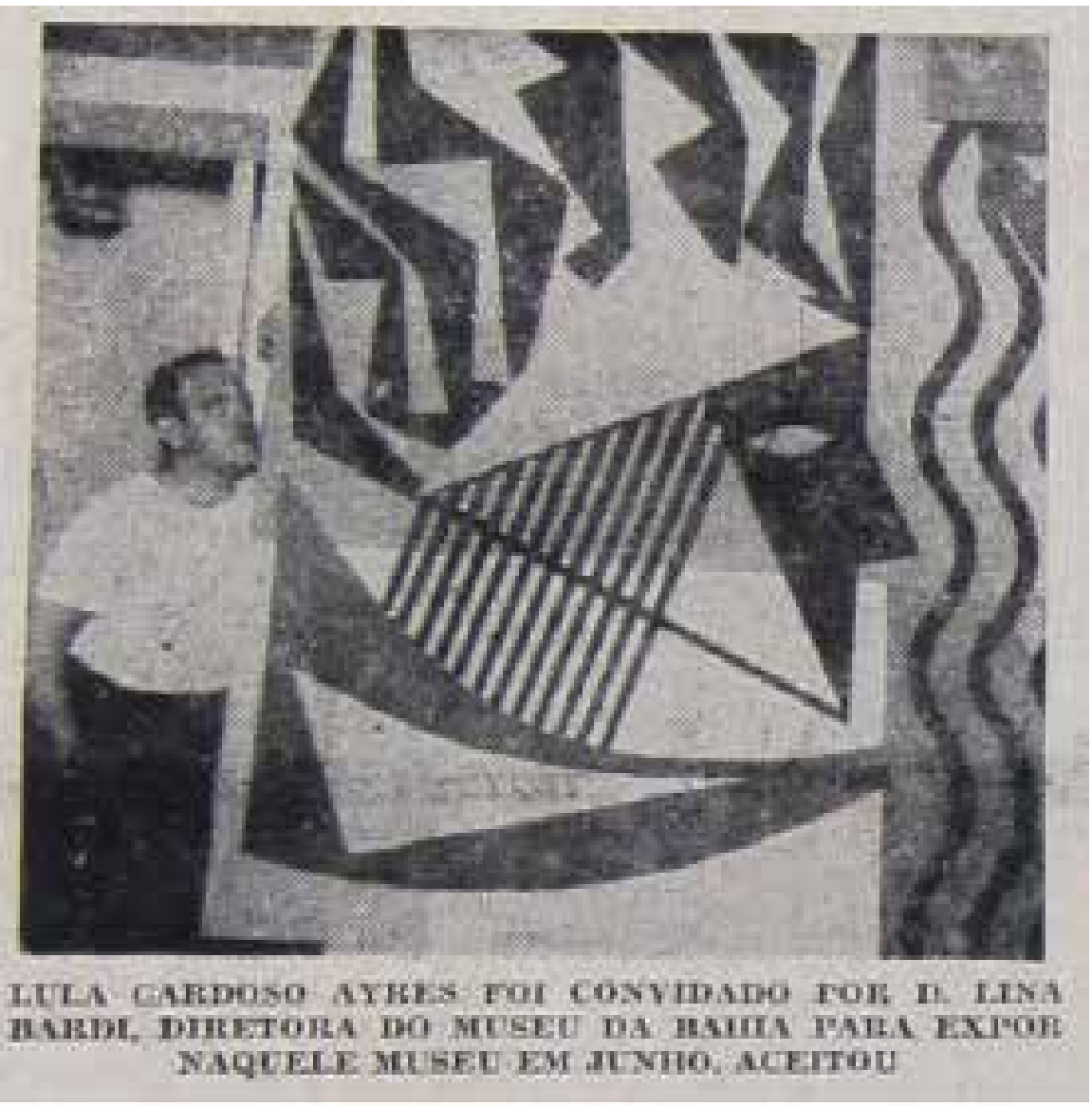

I 4

Lula Cardoso Ayres

Foto publicada na página Arte-Ladjane

em I3/04/I96 I 


\section{CONDICIONANTES PARA O RETORNO AO REGIONAL}

A hesitação entre uma arte abstrata e as referências ao universo regionalista que terminaram por marcar a produção de Lula podem ser compreendidas se forem levados em consideração alguns fatores, entre eles, a sua formação, o ambiente político e intelectual de Pernambuco, sua reclusão na usina Cucaú, sua dependência financeira da venda de sua força de trabalho após a herança familiar ter sido dilapidada e sua insegurança quanto ao que produzia - necessitava constantemente da aprovação dos pares.

Logo, o jovem aprendiz de I 2 anos passou a dispor de um ateliê próprio, montado no maior quarto da antiga senzala do sobrado da rua Benfica. É com carinho que Ayres lembra suas aulas de desenho e pintura sob orientação de seu primeiro professor, o alemão radicado no Brasil, Heinrich Moser (Ayres, I987).

Formado na Alemanha, Moser chegou ao Recife em igio para executar o projeto arquitetônico, e tornar-se sócio, da Casa Alemã, até então dirigida por sua tia. Uma vez estabelecido, passa a executar trabalhos de artes aplicadas, como os de vitrinista para lojas, ilustrador e decorador.

Nesse primeiro momento de contato com o aluno brasileiro, Moser dedicava-se basicamente à ilustração, à pintura de uma maneira geral e à pintura mural decorativa. Executou capas de livros, ilustrou jornais e revistas, tal como Lula o fará nos primeiros trabalhos profissionais de sua carreira. Decorou, com o auxílio de seu discípulo, o salão do Clube Internacional para o carnaval de I924. Foi também nessa década que Moser iniciou-se na arte dos vitrais. Desenvolveu técnica própria de coloração do vidro enquanto era o responsável pelo projeto arquitetônico, construção e decoração da igreja da usina Estreliana. ${ }^{24}$

De 1922 a I924, Lula foi aluno de Moser. Nesse período, apenas dois outros alunos compunham o corpo de aprendizes. ${ }^{25} \mathrm{O}$ pouco interesse de Moser em aumentar o número de alunos particulares, segundo Clarival do Prado Valladares (I978, p. 64), é um forte indício de que as encomendas garantiam sua renda. As atividades de Moser no início do século, tal qual as de outros artistas, estavam fortemente vinculadas às demandas geradas pela expansão da indústria gráfica e da construção civil. Não é por menos que as obras de Moser eram destinadas ou a jornais e livros ou a prédios públicos, religiosos e residenciais.

É o caso da capa que fez em I925 para o livro de poesia de Leovigildo Júnior (figura I5). Já os vitrais, além dos religiosos executados em igrejas de Recife e Olinda, ${ }^{26}$ apresentam temas históricos, como o instalado no Palácio da Justiça, representando o Primeiro Parlamento Democrático na América, numa referência ao período holandês. Em residência privada, o mote regionalista aparece já nos anos I930, quando Moser cria, por exemplo, o vitral As lavadeiras (figura I6), tema que se tornará recorrente na iconografia pernambucana. 


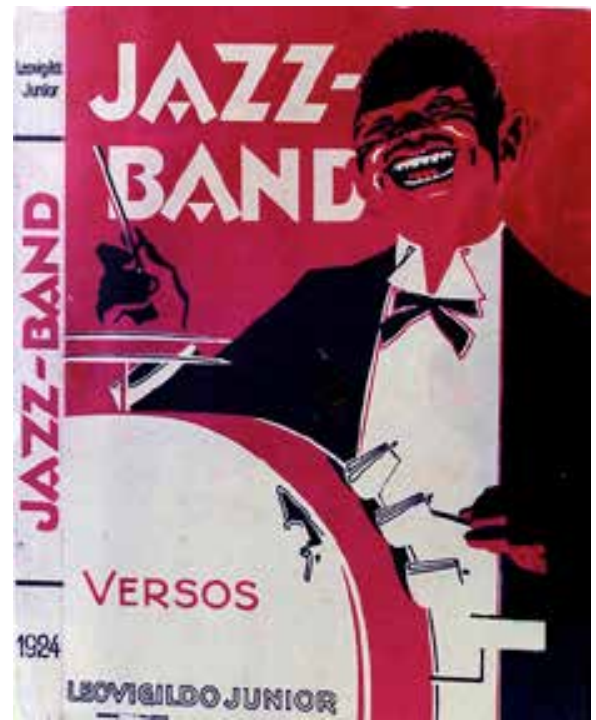

I5

I5

Heinrich Moser

Capa do livro Jazz-Band,

de Leovigildo Junior, I924

Reproduzido em Weber (I987)

I6

Heinrich Moser

As Lavadeiras

Vitral em residência particular, 1930

Reproduzido em Weber (I987)

I7

Heinrich Moser

Retirantes

Vitral em residência particular, 1943

Reproduzido em Weber (I987)
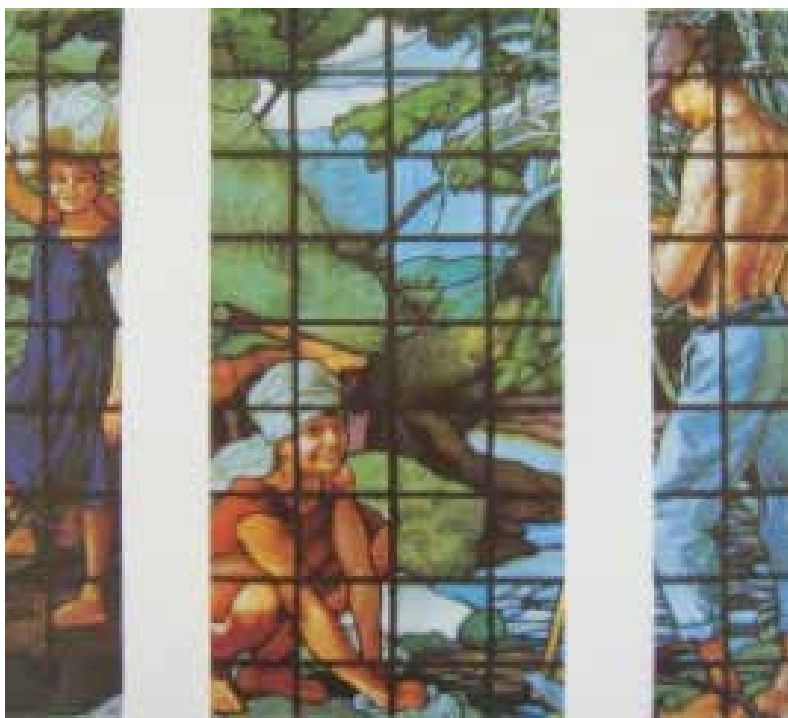

I6

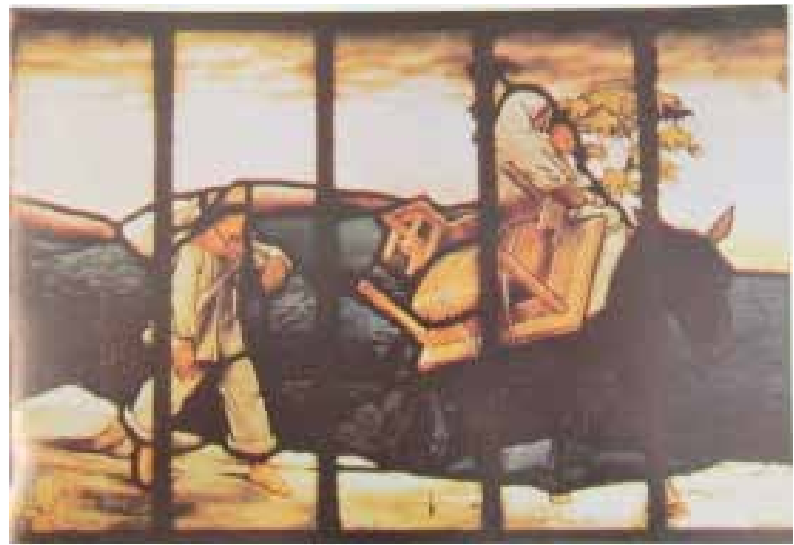

I 7 
Apesar de Clarival do Prado Valladares afirmar que não haveria correlação entre o universo temático de Moser e o de Lula Cardoso Ayres, as reproduções e datações disponíveis evidenciam que há semelhanças pelo viés regionalista, sobretudo nas encomendas particulares feitas ao vitralista.

Lula Cardoso Ayres, no entanto, só esteve próximo de Moser até I924. Passa o ano de 1925 tendo aulas em Paris com o pintor de formação católica Maurice Denis que, com as consequências da Primeira Guerra Mundial e da morte de sua esposa, apega-se ainda mais à religião. Em I922, Denis terminara a execução do projeto da capela de sua propriedade em Saint-Germain-en-Laye, tendo sido responsável pela concepção dos vitrais, pinturas murais, mobiliários, quadros e outros ornamentos. Provavelmente Ayres conheceu a capela. ${ }^{27}$

As aulas, que possivelmente Lula tomou no Atelier de Arte Sacra, fundado por Denis e George Desvallières, devem ter reforçado sua formação no que tange às funções decorativas da arte. Como já mencionado, não há nenhum registro do período parisiense de Lula nos arquivos de Maurice Denis e, também, poucos escritos comentando essa estada.

Ao regressar da Europa, instalou-se no Rio de Janeiro, onde teve aulas com Carlos Chambelland, outro artista que morou no Recife durante três anos (I9I2-I9I5) e trabalhou profissionalmente com artes decorativas. Era um entusiasta da pintura com motivos "tipicamente regionais". Disse o pintor em depoimento de i927:

[As tendências da nossa pintura] devem ser peculiares ao nosso povo, à nossa inclinação nativista, à nossa natureza. Para pintarmos à maneira da Europa, com técnica da Europa, as cenas da Europa, não vale a pena trabalhar. [...] A natureza europeia é calma, de aspectos diferentes dos nossos e parece que está nos dizendo: pinta-me. [...] Tudo aqui pede nova técnica, nova maneira, novos processos picturais. [...] E como para essa obra de criação é necessário em primeiro lugar estudar o povo, no que ele oferece de tipicamente regional, cumpre-nos perlustrar o interior pesquisando o que resta de original, não maculado pela influência estrangeira, para tentar, verdadeiramente, a pintura brasileira, a arte nacional (Chambelland, I927, p. I45).

Em outro trecho, Chambelland destaca o Norte do país como a região em que a nacionalidade brasileira estaria mais preservada do "cosmopolitismo" descaracterizador de nossa "pureza inicial". Caberia aos artistas entrar em sintonia com a "gente do Norte" para captar o "sentimento da pátria" impregnado na "vibração da alma do povo".

A orientação do pintor brasileiro, que pense comigo, neste ponto, tem de ser a procura do convívio da gente do Norte, onde senti - eu que sou carioca, aqui sempre vivi e só saí duas vezes para a Europa - o verdadeiro espírito da nacionalidade, o orgulho de ter nascido aqui. O Rio e o Sul do país estão muito trabalhados pela influência estrangeira, o cosmopolitismo absorveu-nos tanto, que hoje, somente no Norte, se nos depara, em sua pureza inicial, o sentimento da pátria aferrando à tradição, aos costumes, à vibração da alma do povo. Acredite, pela primeira 
vez envaideci-me de minha nacionalidade, quando vivi três anos - os melhores de minha vida - em Pernambuco, recebido com carinho, com um afeto, que não são muito comuns por aqui, no seio daquela gente, amiga e boa, que se excede na própria gentileza para agradar ao hóspede (Chambelland, I927, p. I45, grifos nossos).

Chambelland orientou Ayres em desenho a partir de molde de gesso, mas, como salienta Valladares, não parece ter sido apenas a técnica que o mestre carioca transmitiu ao aluno. ${ }^{28}$ Desse modo, as escolhas que Lula fez ao longo de sua formação não o levaram a assumir pontos de vista diferentes dos de seus professores. Do mestre alemão em Recife ao mestre carioca no Rio de Janeiro, passando por Maurice Denis em Paris, a arte decorativa, o figurativismo e o regionalismo funcionaram como uma linha de prumo, balizando boa parte das experiências expressivas do jovem artista.

Ao retornar ao Recife em I932, Lula encontrou a cidade um tanto em polvorosa. Um forte sentimento nativista, inaugurado com a expulsão dos holandeses séculos antes, foi reativado com acontecimentos de diferentes escalas. A Revolução de I930, tal como foi sentida por parte dos pernambucanos, transformou-se numa guerra contra o "desejo separatista" dos paulistas. ${ }^{29}$ Ao longo dos anos I930, o centralismo criado por Vargas diminuiu ainda mais o poder das elites locais, fazendo com que muitos se sentissem excluídos do jogo político e incitados a reanimar o discurso nativista.

Um evento narrado nas memórias de Paulo Cavalcanti ${ }^{30}$ permite recuperar o clima vivido no Recife nos primeiros anos da Revolução, sobretudo em seu caráter mais prosaico. Um operário da empresa comercial portuguesa Teixeira Miranda fora demitido e, em seguida, teria escutado o insulto de um dos sócios: brasileiro, em sua casa comercial, "só precisava mesmo dos burros para puxar carroças". Verdade ou não, o boato se alastrou e foi o estopim para Recife reviver um "mata-mata marinheiro" da época da guerra contra os mascates, entre os dias 8 e 9 de abril de I93I. Inúmeros armazéns, casas comerciais e torrefações de café cujos proprietários eram portugueses foram depredados. A polícia e o Exército mal conseguiram controlar a turba que se deslocava de uma rua para outra do bairro de Santo Antônio.

O comércio em Recife era, praticamente, todo dominado por imigrantes ou pessoas de origem estrangeira. Armazéns, padarias e torrefações estavam nas mãos dos portugueses; a importação de máquinas, motores e produtos químicos era feita por ingleses e alemães; ${ }^{31}$ as lavanderias, pelos chineses; por judeus, as movelarias, o comércio de joias e o sistema de crédito; por "turcos", a rede de armarinhos e o comércio ambulante de lenços e gravatas; os italianos controlavam as cadeiras de engraxates.

Em outras palavras, na vida cotidiana da cidade, a presença dos estrangeiros era forte, e a dos portugueses, pelo fato de estarem associados à colonização e aos gêneros alimentícios, aparecia ainda mais. O incômodo era tal, 
que, já em dezembro de I930, o novo governo instituído criou a "lei dos 2/3", obrigando que dois terços do comércio e da indústria estivessem sob controle de brasileiros. A lei não foi aplicada em sua totalidade desde sua promulgação. Os fatos de abril de I93I pressionaram o governo a efetivá-la. "As dilações no cumprimento das normas legais é que exacerbaram os ânimos dos pernambucanos, numa cidade em que a maioria das grandes casas de comércio [...] se concentravam, realmente, nas mãos dos lusos" (Cavalcanti, I980, p. I04).

Ao chegar no Recife em I932, sete anos após ter deixado a cidade, Ayres encontrou esse sentimento nativista dominando diferentes esferas da vida; o discurso regionalista engrossado pela produção cultural da elite letrada, manifesta em livros de poesia, romances, artigos de jornal, congressos, suplementos literários. Por outro lado, sua formação em Paris e no Rio parece ter-se mantido em sincronia com o nativismo e o regionalismo. Essas viagens, ao que tudo indica, não deslocaram o seu olhar. Foram poucos os eventos desconcertantes que lhe teriam permitido pensar sua carreira de maneira distanciada ou vislumbrar outro caminho criativo como ocorreu com os irmãos Rego Monteiro e com Cícero Dias. Nesse contexto nativista, qualquer referência às vanguardas ou a uma pintura europeia era tida como indício de "cosmopolitismo" e fortemente rechaçado pela crítica nos jornais. ${ }^{32}$

De volta ao Recife, Lula se ocupa dos negócios familiares. Aproximando-se de Freyre, passa a frequentar xangôs e maracatus. Ao lado de Cícero Dias, Lula é o responsável pela organização do Salão de Artes Plásticas do I Congresso Afro-Brasileiro do Recife, realizado em I934 por Gilberto Freyre e Ulisses Pernambucano. No evento, figuraram objetos de arte afro-brasileira (figas, bonecas e bichos de barro, estandartes de maracatus), pinturas de Lasar Segall, trabalhos de Noemia Mourão, Di Cavalcanti, Santa Rosa; telas dos pintores locais Manoel Bandeira, Hélio Feijó, Luiz Soares, Luis Jardim, Danilo Ramires Azevedo, Nestor Silva, além das dos organizadores, Cícero Dias e Lula Cardoso Ayres.

A rápida integração de Ayres ao projeto regionalista é visível em toda a sua produção a partir da década de I930. No entanto, sua obra não pode ser lida como mero reflexo ou ilustração das palavras de Freyre. Ayres teve um papel criativo importante na composição de um repertório imagético a respeito do que se passou a chamar de "cultura popular", elevada ao status de genuinamente pernambucana que certamente informou Freyre em suas formulações. A maneira como Ayres se movimentou no feixe de relações sociais, que o posicionava e também oferecia caminhos, resultou nas soluções artísticas por ele propostas: os quadros sobre personagens do bumba meu boi, as fotografias de trabalhadores ou cenas de gênero figuradas com bonecos de barro, o olhar atento para as manifestações culturais das classes subalternas.

Permanecendo no Recife, ele se tornou dependente de um ambiente intelectual marcado pelo regionalismo e pelo sentimento nativista o qual de- 
mandava obras que figurassem as tradições populares e especificidades da região. Por outro lado, suas expectativas de reconhecimento para além de Pernambuco tornaram-no também dependente de poucos interlocutores externos, tal como Pietro M. Bardi.

O peso que as opiniões de Bardi acerca de sua obra assumiam aos ouvidos de Lula fica explícito no conjunto de correspondências depositadas no acervo do Masp. Ayres pede sinais de aprovação de Bardi em praticamente todas as cartas. Em uma de io de março de I966, por exemplo, é Lourdes, esposa de Lula, quem escreve a Bardi:

Ando apreensiva com Lula, ele não está passando bem de saúde e anda muito desanimado e deprimido. Não imagina o bem que lhe fez aquele dia que passou aqui. Criou [a Lula] [cara] nova. Voltou a pintar com entusiasmo e fez uns quadros ótimos, bonitos e pintura de verdade.

Lula precisa por todos os motivos fazer uma exposição este ano aí em São Paulo, mas como ele nada resolve sem seus conselhos e seu apoio, peço que lhe escreva sobre esta exposição, que acho de vital importância para sua arte e sua saúde.

Desculpe este pedido mas vejo Lula tão triste e desanimado e com a saúde tão abalada que resolvi escrever-lhe pois sei que uma carta sua é um estímulo para ele.

Lula não sabe que estou lhe escrevendo por isso não toque na minha carta quando escrever-lhe.

Um grande abraço de agradecimento da

Lourdes

Se Lourdes apela para uma carta oculta a Bardi, como recurso para retirar o companheiro do desânimo, pode-se imaginar o quanto eram importantes para Lula as palavras de Bardi a respeito de sua obra.

"Luiz: me fale disto!" é a marcação com letra de Bardi que está presente na carta de Lourdes. Luiz Ossaca, assistente de Bardi, envia carta a Lula oferecendo o Masp para uma exposição em setembro daquele ano, e Bardi envia uma carta anunciando a Lula seu regresso da Europa. Lula responde diretamente a Bardi em 7 de abril de I966: "Suas palavras chegaram para mim como uma benção dos céus, encontrando-me n'uma grande depressão de desânimo! Tenho em Vc. o único estímulo verdadeiro". Mais à frente:

Como já lhe disse meu desejo é ter um apoio verdadeiramente artístico e isto só acontecerá com o seu apoio. [...] Mas como já lhe disse várias vezes, Vc, meu amigo de quem tanto me orgulho, é meu orientador e tudo só farei de acordo com Vc. Meu grande e sincero desejo é fazer este ano uma grande exposição no Museu de Arte com o apoio do querido amigo Bardi!

Sônia Freyre, filha de Gilberto Freyre, também confirma que Ayres era extremamente inseguro e que tinha tendências depressivas. Gilberto Freyre, mais "otimista", nas palavras da filha, animaria o compadre incentivando-o em 
sua carreira. ${ }^{33}$ A estabilidade da relação com Freyre com certeza deve ter colaborado para que Ayres se mantivesse na trilha do regionalismo. Sua insegurança para explorar novas temáticas ou mesmo soluções formais manifesta-se também na insegurança transmitida nas cartas a Bardi.

\section{CONSIDERAÇÕES FINAIS}

Com formação relativamente sólida se comparada aos seus contemporâneos recifenses, não era de estranhar que Ayres mantivesse ambições de atingir o mesmo grau de reconhecimento nacional que desfrutavam, por exemplo, seus conterrâneos Vicente do Rego Monteiro e Cícero Dias. No entanto, esse reconhecimento não foi experimentado por Ayres. As correspondências com Bardi evidenciam suas crises de insegurança a respeito do julgamento de sua produção.

Expõe, em I960 no Masp, o que considerava suas mais ousadas experiências formais para tentar provar aos defensores da "pintura pura" que não era apenas um pintor de folclore. Ao que tudo indica pelas fontes disponíveis, apesar de efetuar algumas vendas, o reconhecimento esperado não veio.

Uma vez rompida a expectativa desse reconhecimento, talvez pela pouca receptividade que obteve do mundo das artes de São Paulo e do Rio de Janeiro (centros legitimadores e já imersos nos desdobramentos dos debates em torno da abstração), as condicionantes pernambucanas ganham novo vigor, e os temas telúricos reaparecem cada vez com mais força em seus trabalhos. Nos anos seguintes, com seu constante afastamento dos círculos de sociabilidade de São Paulo, Lula dedicou-se a pintar temas cada vez mais associados ao "popular" tal como na tela Natal (figura I8), na qual as cores em tom pastel fazem figurar uma cena religiosa com direito a colinas e bois. Com quadros figurativos retratando manifestações populares, Lula segue até sua morte, em I987. Enquanto artista, a única maneira encontrada para continuar pintando foi adequar-se ao que era esperado, por pernambucanos ou paulistas, de um pintor radicado no Recife: pintar as tradições tidas como populares.

Essa escolha faz vir à luz o quanto o regionalismo é antes uma prisão e não uma opção para os artistas pernambucanos não fortemente vinculados a redes de sociabilidade fora do Recife. É comum encontrar formulações, como as do próprio Gilberto Freyre, ou mesmo de Ferreira Gullar citadas neste artigo, que naturalizam as opções estéticas: artistas pernambucanos necessariamente expressariam as particularidades da terra. A trajetória de Lula Cardoso Ayres é emblemática de uma geração de pintores recifenses que se debateram com todas as suas forças para ser reconhecidos no Rio de Janeiro ou em São Paulo para além dos adjetivos regionalizantes.

Vinculando-se ao projeto freyriano de "modernismo regionalista", Ayres vivia uma tensão permanente. Ser um pintor "moderno" no Recife, por ser regionalista e, portanto, folclórico para os críticos da "pintura pura" de São Paulo; 
ou abandonar cada vez mais os regionalismos e ser tido no Recife como um "cosmopolita".

A vinculação ao projeto regionalista foi frutífera para Lula, mas também imprimiu limites claros ao alcance de sua criação. O reconhecimento de Gilberto Freyre ao seu trabalho certamente criou oportunidades, mas, por outro lado, o sociólogo de Apipucos o apresenta aos visitantes do Masp como um pintor "moderno" por ser regionalista. O que, aos olhos de Freyre, era um argumento de positivação de sua obra passou a ser o ruído que Lula queria eliminar para ser aceito entre os defensores da "pintura pura".

Recebido em Io/I/20I7 | Revisto em 23/IO/20I7 | Aprovado em 27/I 2/2017

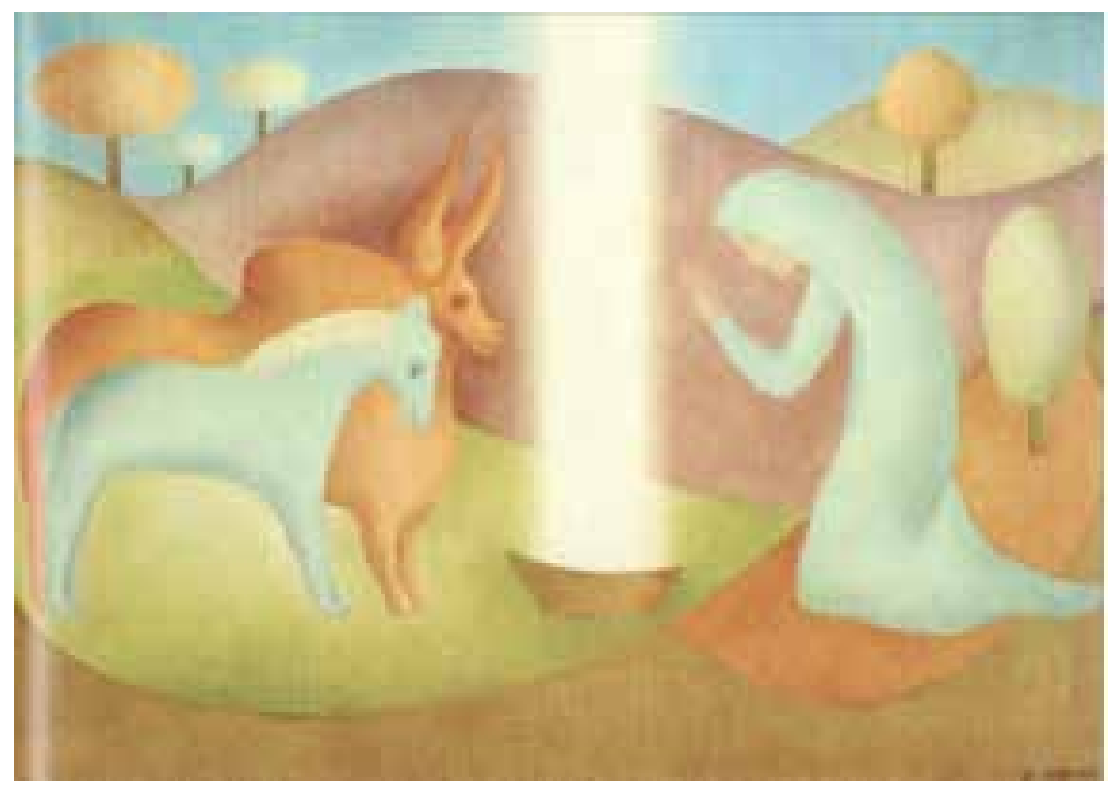


508

Eduardo Dimitrov é professor do Departamento de Sociologia da Universidade de Brasília (UnB) e vice-coordenador do Núcleo de Estudos de Arte e Poder no Brasil (IEB-USP). Doutor (2014) e mestre (2006) em antropologia social pela Universidade de São Paulo com estágio doutoral na École Normal Supérieur, em Paris (20 I I20I 2), suas pesquisas versam sobre a produção cultural desenvolvida em Pernambuco. Entre outras publicações é autor de O Brasil dos espertos: uma análise da construção social de Ariano Suassuna como criador e criatura (20I I) e de "Vicente do Rego Monteiro: de expoente modernista a integralista esquecido" (2015). 


\section{NOTAS}

* A pesquisa que embasou este artigo foi financiada pela Fapesp entre 2009-20I4 e Capes/PDEE entre 20I I e 2012.

I Essa informação é confirmada em praticamente todas as biografias. No entanto, em pesquisa aos arquivos de Maurice Denis, em Saint-Germain-en-Laye, não foram encontrados vestígios de sua passagem no ateliê do artista francês. A falta de informação direta, porém, não significa que Lula não tenha estado junto ao artista. O mais provável é que sua ligação tenha sido um tanto informal, não deixando traços duradouros. Pelas datas, pode-se pensar que Lula Cardoso Ayres tenha sido aluno de Denis nos Ateliês de Arte Sacra. Sabe-se, por exemplo, que Anita Malfatti também foi aluna de Denis anos antes, em 1923. No entanto, nenhuma informação foi encontrada a respeito de possíveis contatos entre Ayres e Malfatti; pouco sabemos ainda a respeito do contato de Ayres com os muitos outros brasileiros que também se dirigiram a $\mathrm{Pa}$ ris nos anos I920, como aponta Marta Rossetti Batista (20I2).

2 Rodolfo Amoedo (Salvador, I857-Rio de Janeiro, I94I). Estuda no Liceu de Artes e Ofícios no Rio de Janeiro, com Victor Meirelles (1832-1903) e Antônio de Souza Lobo (I840-I909); entre I873 e I874 na Academia Imperial de Belas Artes. Viaja para Paris em 1879 , onde estuda na Académie Julian e na École National Supérieure des Beaux Arts. Em I888, é nomeado professor honorário de pintura histórica na Academia Imperial de Belas Artes. Foi professor de artistas como Baptista da Costa (1865-1926), Eliseu Visconti (I866-I944), Candido Portinari (I903-I962), Eugênio Latour (I874-I942) e Rodolfo Chambelland (I8791967) (Instituto..., s.d).

3 Carlos Chambelland (Rio de Janeiro, I884-I950). Frequentou a Escola Nacional de Belas Artes, no Rio de Janeiro, entre I90I e I907. Estudou com Zeferino da Costa (I840I9I5) e Rodolfo Amoedo (I857-I94I). Com o prêmio de viagem ao exterior, frequentou em 1908 o ateliê do pintor Pierre Puvis de Chavannes (I824-I898) em Paris. Em meados de igio, cursou gravura no Liceu de Artes e Ofícios do Rio de Janeiro. Em I9I2, viajou para Pernambuco, onde, durante três anos, realizou trabalhos de decoração e es- 
tudou aspectos e costumes locais para servir de tema à produção de várias pinturas (Instituto..., s.d).

4 O texto que compõe o catálogo da exposição de I96o no Masp foi posteriormente publicado com algumas modificações, sobretudo inclusões de novos parágrafos, no livro de Gilberto Freyre (2oroa) Vida, forma e cor, sob o título "Lula Cardoso Ayres: uma interpretação integrativa de homens e coisas brasileiras".

5 Refere-se a Mário de Andrade, autor de $O$ turista aprendiz e promotor de viagens e missões folclóricas pelo interior do país. Freyre, em alguns momentos, mostra-se ríspido com Mário de Andrade e entusiasta do movimento antropofágico de Oswald de Andrade (cf. Freyre, 20Iob: III).

6 Lula e suas telas participaram do rodamoinho que elevou a escultura figurativa, como as feitas pelo Mestre Vitalino, classificada de "popular" ao status de arte. Colaborou com Lina Bo Bardi em algumas matérias acerca desse tema para a revista Habitat. Uma reportagem sobre Ayres, com farta reprodução de suas telas, foi publicada no mesmo número I2, de setembro de I953, no qual outras matérias ilustradas eram "Roupas de couro do vaqueiro nordestino" e "Paisagem Brasileira", com fotos de igrejas coloniais em meio a pastos de engenho feitas pelo cineasta pernambucano Alberto Cavalcanti.

7 É possível associar essa forma de representar as figuras humanas com o muralismo mexicano. De fato, Ayres e muitos artistas pernambucanos tiveram contato com reproduções das obras de Diego Rivera (I886-I957) e José Clemente Orozco (I883-I949). Especialmente Rivera é citado por Freyre em seus artigos a respeito de Ayres e de sociologia da arte. Não foi encontrado, porém, nenhum depoimento de Ayres ou qualquer outra informação que possa estreitar essa relação. Deixo para os historiadores da arte a exploração, via aspectos formais das telas, das possíveis citações.

8 Como o catálogo é fartamente ilustrado, é possível supor que esses 20 quadros configurem a totalidade das telas que compuseram a exposição. Muitos dos quadros, propriamente ditos, não foram localizados, o que impossibilitou uma análise mais cuidadosa em que fossem considerados detalhes dos aspectos formais. 
9 O catálogo dessa exposição não contém títulos, datas, dimensões e material empregado em cada uma das telas. Aquelas que não foram localizadas são denominadas Título desconhecido e sequenciadas por ordem da aparição neste texto.

Io Entre os pintores pernambucanos, é fato recorrente ter como mote os telhados do Recife. Manoel Bandeira, Wilton de Souza, Lula Cardoso Ayres são alguns, entre outros, artistas que retrataram esse tema.

I I Mauro Ramos da Mota e Albuquerque (I9II-I984) formouse pela Faculdade de Direito do Recife em i937. Além de professor, trabalhou como secretário, redator-chefe e diretor do Diário de Pernambuco. Diretor executivo do Instituto Joaquim Nabuco de Pesquisas Sociais entre I956 e I97I, foi um importante cronista da vida artística de Pernambuco.

I2 Para mais detalhes sobre Frederic James ver Falk (I999) e Falk \& Bien (I990).

I3 As cartas aqui mencionadas encontram-se depositadas na pasta de documentos de Lula Cardoso Ayres na biblioteca do Masp.

I4 Niomar Moniz Sodré (I9I6-2003) era então a diretora executiva do MAM-Rio. Em I96I, Lula faz uma exposição no MAM-BA e, em 1962, na Galeria Bonino, no Rio de Janeiro. Não foram encontradas, no entanto, referências a alguma exposição no MAM-Rio nesse período, como ele desejava. Lula já havia realizado uma mostra no MEC, em I946, e outra no MAM-Rio, em 1952.

I5 Aberto ao público em janeiro de I960, o Museu de Arte Moderna da Bahia - MAM-BA foi encabeçado por Lina Bo Bardi com apoio do governo local. Para mais detalhes ver: Instituto... (s.d.); Rubino (2002).

I6 Ayres refere-se à Escola de Belas Artes de Pernambuco, onde lecionava.

I7 Lula trabalhou por longo período como programador visual. Nas cartas faz menção a sua relação com a tipografia e como isso o ajudara a desenvolver o catálogo.

I8 Carta de Lula Cardoso Ayres a P.M. Bardi, datada de 8/3/1960. Depositada na pasta do artista no Masp. 
I9 Carta de P.M. Bardi a Lula Cardoso Ayres, datada de 22/I/ı960. Depositada na pasta de Lula Cardoso Ayres no Masp.

20 Carta de P.M. Bardi a Lula Cardoso Ayres, datada de I4/3/1960. Depositada na pasta de Lula Cardoso Ayres no Masp.

2I Carta de Lula Cardoso Ayres a P.M. Bardi, datada de 8/3/1960. Depositada na pasta do artista no Masp.

22 Wilton de Souza, pintor pernambucano contemporâneo e amigo de Lula Cardoso Ayres, afirmou, em depoimento ao autor em junho de 20I0, que sempre debatia com Lula a respeito de as manifestações culturais locais deverem ser a base da arte pernambucana e de estilizações poderem ser feitas desde que não "descambassem para a caricatura". Segundo Wilton de Souza, o limite entre estilização e caricatura era um ponto-chave do debate entre os artistas pernambucanos.

23 José Cláudio da Silva foi um dos pintores integrantes do Atelier Coletivo, importante agremiação do início dos anos I950 no Recife que reuniu os artistas Abelardo da Hora, Gilvan Samico, Wellington Virgolino, Wilton de Souza, Corbiniano Lins, entre outros.

24 José Cláudio da Silva (2010, p. I58-I59) descreve a técnica desenvolvida: "em princípio pintor, começou a fazer vitral em I92I, por ter adquirido de um alemão de passagem por aqui por Pernambuco uma prensa de fazer caneluras de chumbo como a da escola onde estudou na Alemanha. Dada a dificuldade de encontrar ou produzir vidros coloridos - a dificuldade principal era não ter uma mufla -, adotou um processo 'de sua invenção' de caneluras de duplo sulco que permitia a incrustação de dois vidros, um pintado e outro protegendo a pintura. Como nos informa pessoa de sua família".

25 Conforme José Cláudio da Silva (2010, p. I59), os outros dois alunos eram Percy Lau e Nenah Boxwell; foram citados no catálogo da exposição que Moser realizou junto com Baltazar da Câmara em 1922 no Gabinete Português de Leitura. Não há muita informação disponível sobre Boxwell, a não ser de que era filha de norte-americanos.

26 As intervenções de Moser nas igrejas pernambucanas geraram, posteriormente, polêmica. Na época em que foram executadas, esses prédios não estavam ainda associados 
à noção de patrimônio material, de modo que Moser gozou de grande liberdade estilística. A partir dos anos I940, tais intervenções serão tidas como responsáveis por descaracterizar a arquitetura e a decoração original, e algumas igrejas passaram por processo de restauro.

27 Para mais detalhes sobre Maurice Denis, ver Lecomte \& Stahl-Escudero (2012). Para o Grupo Nabis, ao qual Maurice Denis estava ligado, ver Fossier (I993) e Frèches-Thory (2002).

28 Essas opiniões de Chambelland são mais próximas das proferidas por Freyre em sua palestra para os alunos da Faculdade de Direito, em I946, do que daquelas pregadas em 1925, no Liuro do Nordeste (que não operava com categorias como "povo" e "espírito de nacionalidade"). Ao explorar as diferenças de concepção de pintura entre o artigo de Freyre de r925 e esse depoimento de Chambelland, de I927, é possível matizar as concepções regionalistas de Freyre presentes no Liuro do Nordeste e, ao mesmo tempo, pensar sobre a contribuição dos pintores para sua elaboração do regionalismo.

29 Como conta Paulo Cavalcanti (I980: 96): "ativados por essa propaganda, odiamos o povo paulista, os motorneiros da 'locomotiva' de que éramos nós, pobres Estados do Nordeste, meros 'vagões de carga'”.

30 Paulo Cavalcanti (I9I5-I995), advogado, escritor e jornalista, foi um importante quadro do Partido Comunista Brasileiro em Pernambuco. Ocupou diferentes cargos eletivos ao longo de sua vida. Durante a ditadura militar, advogou a favor dos presos políticos entre eles Gregório Bezerra, Miguel Arraes e Pelópidas Silveira. Para uma rápida biografia de Paulo Cavalcanti, ver Vainsencher (s.d.).

3I Donde se compreende a facilidade que Heinrich Moser teve em fazer importar a prensa e o maquinário necessário para a fabricação de seus vitrais.

32 Vicente do Rego Monteiro, por exemplo, foi considerado, pela imprensa local, um artista parisiense mais parisiense do que pernambucano. Para mais detalhes, ver Dimitrov (2015).

33 Lourdes Cardoso Ayres foi madrinha de crisma de Sônia Freyre que, por sua vez, foi madrinha de Lula Cardoso 
Ayres Filho. Os filhos de Freyre chamavam o pintor de tio Lula, assim como o antropólogo era chamado de tio Gilberto pelos filhos de Lula dado o grau de proximidade entre as famílias. Depoimento de Sônia Freyre ao programa Espaço Pernambuco, Rede Globo de televisão.

\section{REFERÊNCIAS BIBLIOGRÁFICAS}

Ayres Filho, Lula Cardoso \& Cardoso, Regina Ayres. (2007). Lula Cardoso Ayres: pintor, fotógrafo, artista plástico. Recife: FacForm.

Ayres, Lula Cardoso. (I960). Lula Cardoso Ayres. São Paulo: Museu de Arte de São Paulo.

Ayres, Lula Cardoso. (1987). Meu mestre de sempre Heinrich Moser. In: Weber, Angela Távora (ed.). Moser: um artista alemão no Nordeste. Recife: Pool Ed.

Batista, Marta Rossetti. (20I2). Os artistas brasileiros na escola de Paris: anos 1920. São Paulo: Editora 34.

Caixa Econômica Federal. (20I0). Exposição Galeria Caixa Brasil: a maior mostra simultânea de artes visuais já realizada no país. [s.1.] Caixa Econômica Federal.

Cavalcanti, Paulo. (I980). O caso eu conto como o caso foi da Coluna Prestes à queda de Arraes: memórias. 3. ed. Recife: Guararapes.

Chambelland, Carlos. (1927). Carlos Chambelland. In: Costa, Angyone (ed.). A inquietação das abelhas. Rio de Janeiro: Pimenta de Mello \& Cia.

Dimitrov, Eduardo. (20I5). Vicente do Rego Monteiro: de expoente modernista a integralista esquecido. Novos Estudos Cebrap, São Paulo, I03, p. 193-208.

Falk, Peter Hastings (org.). (1999). Who was who in American art: 400 years of artists active in America, 1564-1975. 2nd printing ed. Madison: Sound view press.

Falk, Peter Hastings \& Bien, Andrea Ansell (orgs.). (I990). The annual exhibition record of the Art institute of Chicago, I888-I950. Madison: Sound view press.

Fossier, François. (1993). La nébuleuse nabie: les nabis et l'art graphique. Paris: Bibliothèque nationale/Réunion des musées nationaux/Diffusion, Seuil. 
Frèches-Thory, Claire \& Terrasse, Antoine. (2002). Les nabis. Paris: Flammarion.

Freyre, Gilberto. (2010a). Lula Cardoso Ayres: uma interpretação integrativa de homens e coisas brasileiras. In: Vida, forma e cor. Recife: É Realizações.

Freyre, Gilberto. (20Iob). Modernidade e modernismo nas artes; Lula Cardoso Ayres: uma interpretação integrativa de homens e coisas brasileiras. In: Vida, forma e cor. Recife: É Realizações, p. I07-I24.

Freyre, Gilberto. (1960). A síntese Lula Cardoso Ayres: arte, região e tempo. In: Lula Cardoso Ayres/Museu de Arte de São Paulo. Recife: Indústria Gráfica Brasileira SA.

Fundação Joaquim Nabuco. (20II). Trabalhadores do campo. Coletiva, Recife, 3. Disponível em <http://www.coletiva.org/site/index.php?option $=$ com_content \&view $=$ articl e\&id=282:trabalhadores-do-campo \&catid $=\mathrm{I} 8 \&$ Imid $=69 \mathrm{\#}$. Acesso em 24 jan. 201 I.

Gullar, Ferreira. (1965). Opinião 65. Revista Civilização Brasileira, Rio de Janeiro, I/4, p. 22I-226.

Instituto Itaú Cultural. (s.d.). Enciclopédia Itaú Cultural de Artes Visuais. Disponível em <http://www.itaucultural.org. br/aplicexternas/enciclopedia_ic/index.cfm $>$. Acesso em 20 nov. 2013.

Lecomte, Vanessa \& Stahl-Escudero, Fabienne (ed.). (2012). Maurice Denis: l'éternel printemps. Paris: Hazan/Musée des impressionnismes.

Mota, Mauro. (I946). "Revelação" de Lula Cardoso Ayres. Nordeste: mensário de cultura, 2/2, p. 6 .

Rubino, Silvana. (2002). Rotas da modernidade: trajetória, campo e história na atuação de Lina Bo Bardi, I947-1968. Tese de Doutorado. PPGA/Universidade Estadual de Campinas. Silva, Alberto da Costa e. (2009). O quadrado amarelo. São Paulo: Imprensa Oficial do Estado de São Paulo.

Silva, José Cláudio. (20I0). Memória do Atelier Coletivo; artistas de Pernambuco; tratos da arte de Pernambuco. 2. ed. Recife: Governo do Estado de Pernambuco.

Silva, José Cláudio. (I96I). A respeito de Wellington. Diário da Noite, Recife, I5/99. 
LULA CARDOSO AYRES: MODERNISTA EM PERNAMBUCO, FOLCLÓRICO EM SÃO PAULO

516

Vainsencher, Semira Adler. (s.d.). Paulo Cavalcanti. Pesquisa Escolar Online. Recife: Fundação Joaquim Nabuco. Disponível em <http://basilio.fundaj.gov.br/pesquisaescolar/>. Acesso em I 2 nov. 2013.

Valladares, Clarival do Prado. (1978). Lula Cardoso Ayres revisão crítica e atualidade. Recife/Rio de Janeiro: Construtora Norberto Odebrecht. 
Palavras-chave

Modernismo;

Lula Cardoso Ayres;

regionalismo; arte e poder; arte brasileira.
LULA CARDOSO AYRES: MODERNISTA EM PERNAMBUCO, FOLCLÓRICO EM SÃO PAULO

Resumo

A circulação de intelectuais e artistas pelo território nacional não se dá de maneira simples e livre de disputas políticas e simbólicas. Essas tensões tornam-se evidentes nas trajetórias de pernambucanos integrantes do modernismo e nas expectativas de reconhecimento desses artistas por seus pares paulistas e cariocas. A trajetória de Lula Cardoso Ayres é emblemática. Como herdeiro do açúcar, teve condições de formar-se pintor frequentando as melhores instituições e artistas renomados. Em Paris, seguiu percurso formativo comparável ao de outros expoentes do modernismo brasileiro. Sua carreira, porém, é marcada por um constante embate entre suas pretensões de reconhecimento nacional e a resistência do campo que, com frequência, o classificava de "regional" ou "folclórico". Ao se confrontar a obra pictórica com comentários críticos publicados na imprensa, textos de Gilberto Freyre e cartas trocadas entre Ayres e Pietro Maria Bardi, esse embate se explicita.

\section{LULA CARDOSO AYRES: A MODERNIST IN PERNAMBUCO, A FOLK ARTIST IN SÃO PAULO}

Keywords Modernism; Lula Cardoso Ayres; regionalism; art and power; Brazilian art.

\section{Abstract}

The movement of intellectuals and artists through the Brazilian national territory is not free from political and symbolic disputes. Some tensions become evident in the trajectories of Pernambuco's modernist artists as they sought recognition by their national peers. The trajectory of Lula Cardoso Ayres is emblematic. Born to a wealthy family, he was able to learn with the most renowned artists. In Paris, his course of training was similar to other exponents of Brazilian modernism. He is considered to be one of the great painters from Pernambuco. His career, however, is marked by a constant tension between his pretensions to national recognition and a resistance from the art world that often classified him as "regional" or "folkloric". This tension is made explicit when we confront his pictorial works with critical comments published in the press, texts by Gilberto Freyre and letters exchanged between Ayres and Pietro Maria Bardi. 